\title{
Gender-related disparities in the frequencies of PD-1 and PD- L1 positive peripheral blood $T$ and $B$ lymphocytes in patients with alcohol-related liver disease: a single center pilot study
}

\author{
Beata Kasztelan-Szczerbinska ${ }^{\text {Corresp., } 1}{ }^{,}$, Katarzyna Adamczyk ${ }^{1}$, Agata Surdacka $^{2}$, Jacek Rolinski ${ }^{2}$, Agata Michalak ${ }^{1}$, \\ Agnieszka Bojarska-Junak ${ }^{2}$, Mariusz Szczerbinski ${ }^{3}$, Halina Cichoz-Lach ${ }^{1}$ \\ ${ }^{1}$ Department of Gastroenterology with Endoscopy Unit, Medical University of Lublin, Poland, Lublin, Poland \\ 2 Department of Clinical Immunology, Medical University of Lublin, Poland, Lublin, Poland \\ 3 Department of Gastroenterology with Endoscopy Unit, Public, Academic Hospital No 4, Lublin, Lublin, Poland \\ Corresponding Author: Beata Kasztelan-Szczerbinska \\ Email address: beata.szczerbinska@op.pl
}

Background. Exposure to excessive alcohol consumption dysregulates immune signaling. The programed cell death 1 (PD-1) receptor and its ligand PD-L1 play a critical role in the protection against immune-mediated tissue damage. The aim of our study was evaluation of the PD-1/PDL-1 expression on peripheral T and B lymphocytes, its correlation with markers of inflammation and the severity of liver dysfunction in the course of alcoholrelated liver disease (ALD). Material and Methods. 56 inpatients with ALD (38 males, 18 females, aged $49.23 \pm 10.66$ ) were prospectively enrolled and assigned to subgroups based on their: 1/ gender, 2 / severity of liver dysfunction (Child-Pugh, MELD scores, mDF), 3/ presence of ALD complications, and followed for 30 days. Twenty five age- and gendermatched healthy volunteers served as the control group. Flow cytometric analysis of the PD-1/PD-L1 expression on peripheral lymphocyte subsets were performed. Results. General frequencies of PD-1/PD-L1 positive T and B subsets did not differ between the ALD and control group. When they were analyzed based on their gender, significantly higher frequencies of PD1/PD-L1 positive B cells in ALD females compared to controls were observed. ALD females presented with significantly higher frequencies of PD-1+ and PDL1+ B cells, as well as PD-L1+ all T subsets in comparison with ALD males. The same gender pattern of the PD-1/PDL1 expression was found in the subgroups with $\mathrm{mDF}>32$ and MELD>20. No correlations of PD-1+ and PD-L1+ lymphocyte percentages with mDF, CTP and MELD scores, nor with complications of ALD were observed. Significant correlations of PD-L1 positive B cell frequencies with conventional markers of inflammation were found.

Conclusions. Gender-related differences in the frequencies of PD-1/PD-L1 positive T and B cells were observed in patients with ALD. Upregulation of PD-1+/PD-L1+ lymphocytes paralleled both the severity of alcoholic hepatitis and liver dysfunction in ALD females. 
1 Gender-related disparities in the frequencies of PD-1 and PD-L1 positive 2 peripheral blood $\mathrm{T}$ and $\mathrm{B}$ lymphocytes in patients with alcohol-related liver 3 disease: a single center pilot study.

4 Beata Kasztelan-Szczerbinska ${ }^{1 *}$, Katarzyna Adamczyk ${ }^{1}$, Agata Surdacka ${ }^{2}$, Jacek Rolinski², 5 Agata Michalak ${ }^{1}$, Agnieszka Bojarska- Junak ${ }^{2}$, Mariusz Szczerbinski ${ }^{3}$, Halina Cichoz-Lach ${ }^{1}$ 6

71 Department of Gastroenterology with the Endoscopy Unit, Medical University of Lublin, 8 Poland,

92 Department of Clinical Immunology, Medical University of Lublin, Poland,

103 Department of Gastroenterology with the Endoscopy Unit, Public, Academic Hospital No 4, 11 Lublin, Poland

$13{ }^{*}$ Corresponding Author:

14 Beata Kasztelan-Szczerbinska ${ }^{1}$

158 Jaczewski Street, Lublin, 20-954, Poland

16 Email address: beata.szczerbinska@op.pl 
31 Background. Exposure to excessive alcohol consumption dysregulates immune signaling. The 32 programed cell death 1 (PD-1) receptor and its ligand PD-L1 play a critical role in the protection 55 against immune-mediated tissue damage. The aim of our study was evaluation of the PD-1/PDL1 expression on peripheral $\mathrm{T}$ and $\mathrm{B}$ lymphocytes, its correlation with markers of inflammation and the severity of liver dysfunction in the course of alcohol-related liver disease (ALD). Material and Methods. 56 inpatients with ALD (38 males, 18 females, aged 49.23 \pm 10.66 ) were prospectively enrolled and assigned to subgroups based on their: 1/ gender, 2 / severity of liver dysfunction (Child-Pugh, MELD scores, mDF), 3/ presence of ALD complications, and followed for 30 days. Twenty five age- and gender-matched healthy volunteers served as the control group. Flow cytometric analysis of the PD-1/PD-L1 expression on peripheral lymphocyte subsets were performed.

Results. General frequencies of PD-1/PD-L1 positive T and B subsets did not differ between the ALD and control group. When they were analyzed based on their gender, significantly higher frequencies of PD1/PD-L1 positive B cells in ALD females compared to controls were observed. ALD females presented with significantly higher frequencies of PD-1+ and PD-L1+ B cells, as well as PD-L1+ CD4+ and CD8+ T subsets in comparison with ALD males. The same gender pattern of the PD-1/PDL1 expression was found in the subgroups with $\mathrm{mDF}>32, \mathrm{MELD}>20$ and Child C class. However, no correlations of PD-1+ and PD-L1+ lymphocyte percentages with mDF, CTP and MELD scores, nor with complications of ALD were observed. Significant correlations of PD-L1 positive B cell frequencies with conventional markers of inflammation were confirmed.

Conclusions. Gender-related differences in the frequencies of PD-1/PD-L1 positive T and B cells were observed in patients with ALD. Upregulation of PD-1+/PD-L1+ lymphocytes paralleled both the severity of alcoholic hepatitis and liver dysfunction in ALD females.

\section{Introduction}

Alcohol abuse remains a huge problem in the Western world. The available body of evidence indicates that it is associated with the increased prevalence of different chronic disorders i.e. cancers, lung and cardiovascular diseases as well as liver cirrhosis (Yoon \& Chen, https:/pubs.niaaa.nih.gov/publications/surveillance111/Cirr15.pdf). According to data from the National Institute on Alcohol Abuse and Alcoholism, over 80,000 deaths per year in the United 
62 States are attributed to alcohol misuse (National Institute on Alcohol Abuse and Alcoholism,

63 https:/www.niaaa.nih.gov/alcohol-health/overview-alcohol-consumption/alcohol-facts-and-

64 statistics). Also, the high mortality rate due to liver cirrhosis in Poland and other Central and

65 Eastern European countries, as well as in the United Kingdom, Ireland, and Finland (World

66 Health Organization, http://www.who.int/healthinfo/statistics/mortality rawdata/en/; Bosetti et

67 al, 2007) is related mainly to the high per capita alcohol consumption.

68 There is a sufficient body of evidence, that alcohol-attributable end-stage liver disease

69 and liver cancer are entirely preventable (Sheron, 2016; Rehm, Samokhvalov \& Shield, 2013).

70 Therefore, it is vitally important for policy planning to chart the methods leading to the reduction

71 of harmful alcohol consumption. Furthermore, also systematic research in order to implement

72 new diagnostic and therapeutic tools and reach new conclusions should be foster. In comparison

73 to huge advances made in the management of viral hepatitis (vaccines and oral therapies for

$74 \mathrm{HBV}$, oral regimes for HCV), alcohol-related liver disease (ALD) management has lagged.

75 Moreover, patients with ALD are generally identified at the late stages of the disease, and

76 programs for early detection are scarce (Ndugga et al., 2017).

77

Exposure to chronic and excessive alcohol consumption, its breakdown metabolites and

gut-derived endotoxins dysregulate immune signaling and give rise to activation of the local and

79

80

81

82

83

84

85

86

87

88

89

90

91

92

systemic pathways of inflammation (Gao \& Tsukamoto, 2016; Szabo \& Saha, 2015). Toxic

ethanol metabolites including reactive oxygen species (ROS) activate T and B cell clones against self- and modified proteins. Activated B cells can produce immunoglobulins directed both to haptens and native antigens (Szabo \& Saha, 2015; Molina et al., 2010). As a result, the nonresolving inflammatory response may occur leading to ALD development and progression. Furthermore, ethanol misuse contributes to the release of circulating modulators of immunity and inflammation, that affect multiple organs and tissues, potentially causing their failure (Louvet \& Mathurin, 2015; Hernaez et al., 2017). Therefore, the aforementioned responses need to be properly controlled to maintain the mechanisms of tolerance and immune homeostasis.

Recent studies have elucidated the relevance of the programmed cell death 1 (PD-1) receptor and its ligand PD-L1 in inhibition of self-reactive and effector cells and the protection against immune-mediated tissue damage. As a negative regulator, PD-1 exerts a suppressive effect on previously activated $\mathrm{T}$ and $\mathrm{B}$ cells by binding to its ligands PD-L1/PD-L2. It results in inhibition of antigen-specific immune cell proliferation, cytokine release, and cytolytic function.

Peer] reviewing PDF | (2020:06:49751:1:2:NEW 8 Nov 2020) 
93 PD-L1 is also constitutively expressed on T and B cells, dendritic cells (DCs), macrophages, 94 mesenchymal stem cells and bone marrow-derived mast cells (Yamazaki et al., 2002;

95 Boussiotis, Chatterjee \& Li, 2014). PD-1 conducts signals only when it is cross-linked with B- or

96 T-cell antigen receptors. These coinhibitory signals modulate the intensity and duration time of

97 immune reactions and may restrict immune-induced tissue damage, control the resolution of 98 inflammation, and maintain peripheral immune tolerance (Bardhan, Anagnostou \& Boussiotis, 99 2016; Saresella et al., 2012).

100 The PD-1/PD-L1 pathway has been shown to play an important role in a variety of 101 diseases, like cancer, autoimmune conditions, and chronic infections. It has already been 102 investigated using experimental animal models in systemic lupus erythematosus, 103 encephalomyelitis, myasthenia gravis, diabetes mellitus, myocarditis, inflammatory bowel 104 diseases, systemic sclerosis, and rheumatoid arthritis. The critical role of PD-1/PD-L1 signaling 105 in the prevention of disorders caused by impaired immune activation has become evident 106 (Dinesh, Hahn \& Singh, 2010; Zamani et al., 2016). However, its impact on the development and 107 progression of ALD has not been entirely explained yet. It is likely that alterations of the checkpoint inhibitor surveillance may be responsible for long-lasting activation of the inflammatory response in the liver, as well as the systemic character of the disease. Recently Markwick et al. reported that PD-1, and T-cell immunoglobulin and mucin domain-containing protein 3 (TIM3), as well as their ligands i.e. PD-L1 and galectin-9, represented relevant elements of innate and adaptive immunity in the course of alcoholic hepatitis (AH). T lymphocytes from AH patients showed higher expression of PD-1 and PD-L1 in comparison

114 with control T cells. They indicated that PD-1 and TIM3 blockade might create the potential new approach for the treatment of the disease.

On this background, we aimed to explore possible alterations in the expression of PD-1/

117 PD-L1 proteins on peripheral T and B lymphocytes, their eventual correlations with conventional 118 markers of inflammation and the severity of alcoholic hepatitis (AH), as well as with the severity 119 of liver dysfunction classified according to the criteria (Child-Turcotte-Pugh, Model of End120 Stage Liver Disease, modified Maddrey's discriminant function) widely used for this purpose in 121 clinical settings for ALD patients.

122 Since a great body of evidence indicates that compared with their male counterparts, 123 women are more susceptible to the toxic effects of ethanol in the liver for any given dose of 
124 alcohol (Chou, 1994; Greenfield, 2002; Grant et al, 2017; Lowe et al., 2019), and also symptoms 125 and signs in ALD demonstrate sexual dimorphisms, possible gender-related differences in the 126 PD-1/PD-L protein expression were also assessed. Sex hormones have been suggested to 127 influence immune response. These hormones exert their biological effects by binding to the 128 inherent receptors on immune cells, what results in further modification of gene expression, 129 lymphocyte proliferation, antigen presentation, and cytokine secretion (Whitacre, 2001). Females 130 are known to produce higher titers of circulating immunoglobulins, as well as a major variety of 131 autoreactive antibodies. Women also demonstrate a more pronounced humoral immune response 132 against infections in comparison with men (Arroyo \& Montor, 2011). Understanding the 133 background of gender-related differences in the ALD course may be relevant for individually 134 tailored therapies.

135 Materials \& Methods

136 Characteristics of the studied cohort

137 We used the same patient recruitment protocol as presented in our previous studies 138 (Kasztelan-Szczerbinska et al., 2014; Kasztelan-Szczerbinska et al., 2015). In short, 56 139 consecutive inpatients (18 females and 38 males) with ALD were prospectively enrolled over 2 140 years. Twenty- five healthy volunteers who matched for age and sex (9 women and 16 men) 141 served as the control group. Controls confirmed abstinence or declared that their alcohol 142 consumption had not exceeded $10 \mathrm{~g}$ of ethanol daily. The diagnosis of alcohol-related liver 143 disease was based on classic symptoms and signs revealed after a patient's history taking and 144 physical examination in combination with laboratory alterations i.e. increased liver enzyme 145 levels and AST / ALT ratio greater than 2 typically for ALD, as well as results of imaging 146 studies in individuals with alcohol misuse. Taking into account the disease indicators well 147 described and calibrated in prior clinical research, the identification and characterization of the 148 illness in our studied cohort was based on the recommendations of EASL and AASLD without 149 performing a liver biopsy (Stickel et al., 2017). Other etiology of chronic liver injury were ruled 150 out. Alcohol drinking habits were established using the Alcohol Use Disorder Identification Test 151 (AUDIT). A score of less than 5 was serving as a signal of a non-drinker, while an AUDIT score 152 of 8 or more was an indication of harmful drinking. The average drinker score was 32 (Saunders 153 et al., 1993). The positive AUDIT result served as the study inclusion criterion. 
154 Heavy and hazardous alcohol consumption in studied patients was defined by The World Health 155 Organization criteria

156 (http://www.who.int/gho/alcohol/consumption_patterns/heavy_episodic_drinkers_text/en/). In 157 our cohort, the female daily etanol intake ranged from $40 \mathrm{~g} / \mathrm{d}$ to more than $100 \mathrm{~g} / \mathrm{d}$, and male 158 daily intake from $60 \mathrm{~g} / \mathrm{d}$ to more than $100 \mathrm{~g} / \mathrm{d}$. No treatment was administered to any patient at 159 the enrollment. Patient demographics was collected and the established procedures were 160 performed and finished for each individual within 48 hours at hospital admission. The Child161 Turcotte-Pugh (CTP) (Peng, Qi \& Guo, 2016), MELD (Model End-Stage Liver Disease) 162 (Ashwani, Singal \& Kamath, 2013) and modified Maddrey Discriminant Function (mDF) score 163 were used to categorize the liver dysfunction (internet calculators were applied from 164 https://www.mdcalc.com were used).

165 Studied patients were distributed to subgroups based on their:

166 1. gender,

167 2. degree of liver failure classified by CTP, MELD and $\mathrm{mDF}$ scores

168 3. simultaneous medical conditions related to ALD decompensation (ascites, hepatic 169 encephalopathy- HE, esophageal varices, kidney dysfunction).

170 Other potential confounders as blood transfusions during last 6 months before the study entry, 171 history of immune-related comorbidities or allergies, and immunomodulators administration 172 were excluded. Additional severe coexisting disorders such as malignancy, respiratory failure, 173 severe cardiovascular dysfunction, or unstable diabetes mellitus, were also ruled out.

174 West-Haven criteria (Dharel and Bajaj, 2015) were applied to classify signs of overt hepatic 175 encephalopathy. The presence of ascites was checked by ultrasound examination. Esophageal 176 varices were identified by endoscopic examination of upper gastrointestinal tract. Kidney 177 dysfunction was defined by blood creatinine values above $1.2 \mathrm{mg} / \mathrm{dl}$ (i.e. the upper limit of 178 normal).

179 Studied patients were discharged home after liver function parameters stabilized, as well as 180 physical and emotional symptoms and signs of alcohol withdrawal resolved. Follow-up 181 outpatient visits were scheduled every 2 weeks during one month after patient discharge or 182 during every hospital admission if needed.

183 Five (8.9\%) patients died within 30 days of follow-up.

\section{Ethical Requirements}


185 All individuals signed the written informed consent prior to their inclusion in the study with 186 respect to examining their blood samples for scientific purposes and were free to withdraw at any 187 time without providing a reason. Strict confidentiality was maintained throughout the process of 188 data collection and analysis. The study protocol conforms to the ethical guidelines of the 1975 189 Declaration of Helsinki (6th revision, 2008) as reflected in a priori approval by the institutional 190 review board of Medical University of Lublin (KE-0254/141/2010).

\section{Laboratory examinations}

192 Analyses of basic laboratory tests included as follows: liver enzymes (transaminases- ALT, AST, 193 alkaline phosphatase-AP, gamma-glutamyl transpeptidase- GTP), liver function parameters (total 194 bilirubin, albumin, urea, prothrombin time and INR), complete blood count, parameters of renal 195 function, and conventional markers of inflammation (white blood cells count, neutrophils count, 196 neutrophil to lymphocytes ratio, C-reactive protein level).

\section{Cell isolation and flow cytometric analysis}

198 Immunofluorescence examinations were performed based on the combination of 199 allophycocyanin (APC), phycoerythrin (PE)- and fluorescein isothiocyanate (FITC)- labeled 200 monoclonal antibodies (mAbs). All mAbs (BD Biosciences, USA) applied in our study are 201 presented in the Supplementary Tab. S7. Five milliliters of the whole blood obtained by 202 venipuncture from ALD patients and healthy controls were collected into sterile, lithium heparin203 treated blood collection systems (S-Monovette, SARSTEDT AG \& Co., D-51588 Numbrecht, 204 Germany) and incubated with mAbs (20 $\mu \mathrm{l}$ per test) for $20 \mathrm{~min}$. in the dark at room temperature. 205 Next, BD FACS ${ }^{\text {TM }}$ Lysing Solution (BD Biosciences, USA) was applied for 10 minutes in the 206 dark to lyse red blood cells. Subsequently, the samples were washed with Phosphate Buffered 207 Saline (PBS) (Sigma-Aldrich, Germany) solution and analyzed by flow cytometry directly after 208 preparation. A FACSCalibur ${ }^{\mathrm{TM}}$ flow cytometer (BD Biosciences, USA) equipped with $488 \mathrm{~nm}$ 209 argon laser was used for data acquisition and analysis. A minimum of 10,000 events for each 210 analysis were acquired and analyzed with CellQuest Software. For each person, lymphocytes 211 were identified and gated by setting appropriate forward and side scatter parameters. Examples 212 of the cytometric analysis are presented in Supplementary Figures S4 and S5.

\section{Statistical analysis}

214 Statistical analysis was performed using the Statistica 10 software package (StatSoft, Poland).

215 The distribution of the data in the groups was preliminarily evaluated by Kolmogorov and 
216 Smirnov test. A skewed distribution of checked values was found, so continuous variables were

217 presented as medians with interquartile range and assessed using the Mann-Whitney U test.

218 Categorical variables were described as numbers with percentages and compared using either

219 Fisher's exact test or the $\chi 2$ test as appropriate. The differences in the frequencies of PD- 1 and

220 PD-L1 positive lymphocytes between CTP classes were analyzed using Kruskal-Wallis and 221 posthoc Dunn's multiple comparisons test. Spearman's rank correlation test was used for the 222 assessment of correlations between the frequencies of PD-1/PD-L1 positive T and B cells and 223 liver function parameters, as well as standard indices of inflammation. The receiver operating 224 curves (ROC) were constructed and their areas under the curve (AUCs) checked in order to 225 estimate potential accuracy of selected frequencies of PD-1/PD-L1 positive lymphocytes as a 226 discrimination measure in liver dysfunction modelling. The method of DeLong, (DeLong \& 227 Clarke-Pearson, 1988), for the calculation of the Standard Error of the AUC was used.

228 Youden's $J$ statistic was used to define the optimized cut-off values (Schisterman et al., 2005). A 229 two-sided p-value of less than 0.05 was considered to be associated with statistical significance.

230 Results

231 Basic characteristics of the studied groups.

232 Fifty-six patients (pts) met the inclusion criteria and were enrolled in the study, including 38 233 males (67.9\%) and 18 females (32.1\%). Their mean age was $49.54 \pm 10.94$ and $47.78 \pm 12.22$, 234 respectively. Five $(8.92 \% \%)$ of 56 pts with ALD died from complications of liver failure within 23530 days of follow up. The matching control group consisted of 25 healthy volunteers who 236 consumed no more than $10 \mathrm{~g}$ of ethanol per day including $16(64.0 \%)$ males and $9(36.0 \%)$ 237 females aged $46.21 \pm 11.23$ and $45.11 \pm 10.23$, respectively. Several surveys have indicated that 238 the relative risk of alcohol-associated liver injury is higher in females in comparison to males 239 (Loft, Olesen \& Døssing, 1987; Becker et al., 1996; Rehm et al., 2007). Therefore, patients were 240 assigned to two subgroups based on their gender. Nevertheless, both subgroups have not differed 241 significantly regarding their liver function parameters nor demographic data. The baseline 242 characteristics of ALD patients and the control group is summarized in Table 1.

243 Analysis of the PD-1 and PD-L1 positive $T$ and $B$ lymphocyte frequencies in the peripheral 244 blood of patients with ALD in comparison with the control group and gender-related 245 differences. 
246 The general frequencies of PD-1 and PD-L1 positive T and B subsets did not differ between the 247 ALD and the control group (see Supplementary Table S1). Although, when the ALD group were 248 analyzed based on their gender, significantly higher frequencies of PD1 and PD-L1 positive 249 CD19+ B cells in ALD females compared to female controls were observed (Fig. 1; Table 2). 250 There were no statistically significant differences in the frequencies of PD-1/PD-L1 positive T 251 and B cells between the ALD and control groups of the studied men (Table 2).

252 Furthermore, females with ALD presented with significantly higher frequencies of PD-1 and PD253 L1 positive B cells, as well as PD-L1 positive T cells (both subsets) in comparison with ALD 254 males (Table 2).

255 There were no gender-related differences in the frequencies of PD-1/PD-L1 positive $\mathrm{T}$ and $\mathrm{B}$ 256 lymphocytes in the control group (Table 2).

257 Analysis of mutual correlations between frequencies of PD-1/PD-L1 positive B and T 258 lymphocyte subsets in patients with $A L D$.

259 Significant correlations were observed between frequencies of PD-1 positive CD4+ and CD8+ 260 cells (Rho 0.75), as well as PD-L1 positive CD4+ and CD8+ cells (Rho 0,86). Furthermore, 261 significant correlations were confirmed between frequencies of PD-1 positive B cells (CD19+) 262 and both PD-L1 positive T subsets (Rho 0.37 for CD4+; Rho 0.41 for CD8+), as well as PD-L1 263 positive $\mathrm{B}$ (Rho 0.39) and PD-L1 positive CD4+ (Rho 0.33) and CD8+ (Rho 0.35) T cells.

264 Furthermore, frequencies of PD-L1 positive B cells (CD19+) showed a positive correlation with 265 both PD-L1 positive T cell subsets (Rho 0.75 for CD4+; Rho 0.77 for $\mathrm{CD} 8+$ ). (Rho= Spearman's 266 correlation coefficient) (Supplementary Table S8). Similar mutual correlations were seen for 267 CD19+ subsets in the control group. (Supplementary Table S7)

268 Correlations of the frequencies of PD-1/PD-L1 positive T and B lymphocytes with 269 conventional markers of inflammation in patients with $A L D$.

270 Significant correlations of the CD19+PD-L1+ frequencies with all conventional markers

271 of inflammation (i.e. white blood cell and neutrophil counts, C-reactive protein, and neutrophil-

272 to-lymphocyte ratio) were found. Moreover, frequencies of CD19+PD-1+ and CD4+PD-L1+ 273 cells revealed a positive correlation with white blood cell and neutrophil counts (see Table 5).

274 Correlations of the frequencies of PD-1 and PD-L1 positive lymphocytes with liver function 275 parameters and severity scores /MELD, CTP, $\mathrm{mDF}$. 
276 There were no correlations of any frequencies of PD-1/PD-L1 positive lymphocytes with liver 277 enzymes (ALT, AST, AP, GTP) and its synthetic function parameters (bilirubin, albumin, urea, 278 INR) even in relation to patients' gender.

279 The association between the frequencies of PD-1/PD-L1 positive lymphocytes and 280 advanced liver dysfunction defined by MELD score $>20$, CTP C class, and severe alcoholic 281 hepatitis $(\mathrm{AH})$ defined by $\mathrm{mDF}>32$ was also checked. The significant differences were found in 282 the female subgroup (Table 3, 4, 6).

283

284

285

286

287

288

289

290

291

292

293

294

295

296

297

298

299

300

301

302

303

304

305

306

ALD females with CTP class B presented with significantly lower frequencies of PD-1 positive CD4+ T cells in comparison to CTP class A and C (Supplementary Figure S2). Also the frequencies of PD-L1 positive CD8+ cells were significantly higher in CTP class $\mathrm{C}$ in comparison to CTP class B (Supplementary Figure S3; Supplementary Table S3). Moreover, ALD females with MELD $>20, \mathrm{mDF}>32$ and Child class $\mathrm{C}$ differed significantly from ALD males with MELD $>20, \mathrm{mDF}>32$ and Child class $\mathrm{C}$ in regard to the frequencies of PD-1 positive B and all subsets of PD-L1 positive lymphocytes (Table 3, 4, 6; Figure 2-4).

Moreover, our study revealed, that positive correlations existed between frequencies of PD-L1 positive CD8+ cells and mDF score in ALD females (Rho 0.48; $p=0.04$ ) (Table 7). The ROC curve of CD8+PD-L1+cells in predicting mDF above 32 showed sensitivity 100.00 (95\%CI 47.8-100.0); specificity 69.23 (95\%CI 38.6 - 90.9), and an AUC 0.877 (95\%CI 0.640.98). The results were presented in Supplementary Table S8 and Supplementary Figure S3). Applications of ROC curves include assessment of the effectiveness of continuous diagnostic parameters in distinguishing between diseased and non-diseased individuals. As reported elsewhere, AUC has a real clinical significance when its value exceeds 0.7 and AUC values between 0.8 and 0.9 , as were found in our studied cohort, demonstrate excellent diagnostic accuracy (Farcomeni \& Ventura, 2012; Qin \& Hotilovac, 2008).

\section{Correlations between the frequencies of PD-1 and PD-L1 positive lymphocyte subsets and} the presence of ALD complications i.e. ascites, hepatic encephalopathy, esophageal varices, hepato-renal syndrome, and survival.

Correlations between the frequencies of PD-1/PD-L1 positive lymphocyte subsets and ALD complications were also checked in the studied cohort. Of ALD complications, only patients with ascites presented with significantly higher frequencies of PD-L1 positive CD19+ cells in comparison to their non-ascitic counterparts $(\mathrm{p}=0.03)$ and the control group $(\mathrm{p}=0.02)$ (see 
307 Supplementary Table S6). No differences in the frequencies of PD-1+/PD-L1+ lymphocyte

308 subsets were found concerning hepatic encephalopathy (HE), esophageal varices (EV), renal 309 impairment, nor 30-day survival.

\section{Discussion}

311 Innate and adaptive immune responses represent a driving force in the initiation

312 and development of ALD leading to liver fibrosis and subsequent conversion to cirrhosis with

313 eventual further progression to liver cancer in about $\%$ of cirrhotics (Orman, Odena \& Bataller,

314 2013). Regarding advanced liver disease, ALD is the main cause of cirrhosis worldwide,

315 accounting for 50\% of the cases (Poznyak \& Rekve, 2014). Liver dysfunction with loss of the

316 ability to clear immunogenic cellular residues and ethanol metabolites from the systemic

317 circulation results in persistent stimulation of the immune system. Patients who suffer from ALD

318 present not only with the increased titer of circulating antibodies but also with other lymphocyte-

319 mediated responses triggered by antigens originating from oxidative stress (Sutti, Bruzzì \&

320 Albano, 2016). Paradoxically, these patients present with enhanced immune activity and

321 exacerbated inflammatory responses, but are unable to cope with bacterial infections. Their

322 immune effector cells are primed, but antibacterial functions are switched-off (Riva \& Chokshi,

323 2018). The PD-1/PD-L axis represents an important co-inhibitory pathway, which modulates

324 immune system activation and tolerance. However, overexpression of these molecules may

325 contribute to excessive inhibitory signals and lead to an impaired immune response. The PD-

326 1/PD-L1 signaling has been shown to play a pivotal role in different disorders including chronic

327 infections, autoimmune diseases, and cancers (Riva \& Chokshi, 2018; Pardoll, 2012). To date,

328 the effects of checkpoint blockade have not been fully explained in patients with ALD, the

329 disease with no currently approved pharmacological treatment. Although many studies on

330 immune alterations in ALD have been conducted during the last decade, the available body of

331 evidence for the role of the PD-1/PD-L1 signaling is fairly scarce.

332 In general, our results revealed no differences in the frequencies of PD-1/PD-L1 positive $\mathrm{T}$ and $\mathrm{B}$

333 lymphocytes between ALD patients and healthy controls (Supplementary Table S1).

334 Interestingly, the analysis based on patients' gender revealed significant disparities. The studied

335 women with ALD presented with significantly higher frequencies of PD-1 and PD-L1 positive B

336 cells (CD19+) in comparison with female controls (Figure 1, Table 2). Recently, the effect of

337 PD-1 engagement in inducing B cell dysfunction has been also described in HIV infection (Moir 
338 \& Fauci, 2014; Boliar et al., 2012). Furthermore, Huang R. et al., 2016, reported that the density 339 of CD20 positive B cells was significantly increased in the liver tissues of patients with chronic 340 liver disease (CLD) of different etiologies compared to normal liver tissues. CLD patients with a

341 higher hepatitis grade presented with significantly more intense B cell infiltration compared to

342 those with a lower grade of inflammation. Enrichment of B cells in hepatic diseases may

343 implicate this subpopulation in their pathogenesis. Since the development of collateral

344 circulation, as a consequence of portal hypertension, facilitate the interaction of gut-derived

345 antigens and endotoxins (that bypass the liver) with antibody-producing cells,

346 hyperimmunoglobulinemia is frequently seen in patients with ALD (Husby et al., 1977; Tomasi

$347 \&$ Tisdale, 1964). Alterations in the B cells number in heavy alcoholics and patients with ALD

348 have been reported in previous studies (Matos et al. 2013; Zhang et al. 2005). B cells through the

349 immunoglobulin secretion may mediate both T cells- dependent and - independent immune

350 responses (Sha et al., 2019; Parra et al. 2013). Short-term ethanol treatment at high dose down-

351 regulated splenic macrophages and DCs activity via enhancing B cells function as the antigen-

352 presenting cell, and eventually facilitating a microenvironment that leads to increased activation

353 of $\mathrm{CD}^{+} \mathrm{T}$ cells (Andrade et al. 2009). The relevance of B cells in patients with ALD deserves to

354 be further clarified.

355 Furthermore, significant differences were found between females and males in the ALD

356 group. They differed in terms of the frequencies of PD-1 and PD-L1 positive B cells, as well as

357 the PD-L1 positive all T subsets. The aforementioned gender-related immune disparities

358 occurred as a result of the disease because they were not observed in the control group (Table 2).

359 Our findings are consistent with recently published reports that address the role of sex

360 hormones in modulating PD-1/PD-L1 signaling and gender-related efficacy of their blockage

361 (Bardhan, 2016; Wu et al., 2018; Capone et al., 2018). Sex hormones influence both innate and

362 adaptive immune responses by their impact on $\mathrm{T}$ and $\mathrm{B}$ cells, antigen presentation and cytokine

363 secretion (Klein \& Flanagan, 2016). It shed light on the gender-related discrepancy observed in

364 immune disorders. Also, our results confirmed the presence of the sexual dimorphism in immune

365 reactivity during the course of ALD due to a divergence between males and females in the

366 frequencies of PD-1/PD-L1 positive T and B lymphocytes. Previous reports have already

367 provided some evidence of the gender-related differences in morbidity among alcohol abusers,

368 but underlying mechanisms are not well understood (Chou, 1994; Greenfield, 2002). 
369 Drinking alcohol presents a health challenge for women. Even small amounts of alcohol affect 370 women in a more severe way than men and are much more risky for them. Also, our study 371 introduced the evidence, that females with the severe course of ALD defined by MELD>20, CTP 372 class $\mathrm{C}$ or $\mathrm{mDF}>32$ presented with the higher frequencies of PD-1 and PD-L1 positive $\mathrm{B}$ cells 373 (CD19+) and the PD-L1 positive T cell subsets (CD4+, CD8+) in comparison not only with 374 female controls, but also with ALD females whose MELD was $<=20$ and $\mathrm{mDF}<=32$, as well as 375 with their male counterparts with MELD $>20$, CTP class $\mathrm{C}$ and $\mathrm{mDF}>32$ (Table 3, 4, 6; Figure 2376 4). Moreover, women with ALD classified as the CTP class C had significantly higher 377 frequencies of PD-L1 positive CD8+ T lymphocytes in comparison to ALD females with CTP 378 class B (Supplementary Figure S3). Also, frequencies of CD4+PD-1+ were significantly lower in 379 females with CTP class B compared with femalres classified as CTP class A and C 380 (Supplementary Figure 2). Our findings may suggest the impairment in the regulation of immune 381 suppressive mechanisms in women with the severe ALD course. Further functional tests should

382 383 384 385 386 387 388

389 390

391

392 393 394 395 396 397 be performer to confirm our assumption. The results are also consistent with previous reports indicating that PD-L1 is ubiquitously expressed at low levels and strongly induced by proinflammatory signals (Liang et al, 2003). Similar data were obtained by Markwik et al., 2015, who performed the ex-vivo evaluation of immunological features of patients with acute alcoholic hepatitis (AAH) and reported hyperexpression of the PD-1 and PD-L1 proteins on T cells. Moreover, the researchers demonstrated an impaired function of $\mathrm{T}$ lymphocytes obtained from AAH patients what was manifested by decreased production of gamma interferon. Increased numbers of IL-10 synthesizing T cells in response to chronic endotoxin exposure were also observed. Blocking PD-1 and TIM3 reversed the aforementioned effects and restored the antimicrobial activity of both $\mathrm{T}$ lymphocytes and neutrophils. The findings link the PD-1 pathway to the regulation of antibacterial immunity.

The PD-1/PD-L1 expression on peripheral T and B lymphocytes was also found to be increased in other inflammatory disorders. Jia Y et al., 2016, reported an upregulation of PD-1 expression on CD4+ and CD8 $+\mathrm{T}$ cells in severe septic patients and in patients with type 2 diabetes mellitus (T2DM). However, patients with severe sepsis showed higher PD-1 expression in comparison with T2DM patients.

The increased expression of PD-1 on T cells and PD-L1 on monocytes was observed in patients with septic shock in comparison with healthy controls (Zhang et al., 2011). However, 
400 in contrast to our study, the PD-1 expression on B cells (CD19+) and the PD-L1 expression on T 401 (CD4+, CD8+) and B cells (CD19+) were not changed.

402 There are many similarities between severe ALD and sepsis in the context of the immune 403 derangement. Patients with alcohol-associated liver failure, alike septic patients, present 404 with an increased susceptibility to infections as a result of concurrent immune activation 405 and immune exhaustion that seems to be related to the overexpression of negative immune 406 checkpoints causing immunosuppression (Riva \& Chokshi, 2018). It becomes more clear now, 407 why several attempts to attenuate inflammatory response by the administration of antibodies 408 directed against tumor necrosis factor-alpha have brought disappointing results in severe $\mathrm{AH}$ 409 (Naveau et al., 2004).

The PD-1 overexpression on neutrophils in patients with systemic lupus erythematosus 411 (SLE) correlated with the disease activity and severity. Similarly in our study, the frequencies of 412 PD-L1 positive CD8+ correlated with mDF in ALD females (Table 7). The results of Liu, Weng 413 \& Weng, 2009, showed that patients with SLE had significantly increased percentages of PD-1414 expressing CD3+T cells and CD19+B cells, PD-L1-expressing CD19+ B cells, and PD-L2415 expressing CD14+ monocytes. ALD females in our study also presented with significantly 416 higher frequencies of the PD-1/PD-L1 positive B cells (CD19+) compared to female controls 417 (Figure 1, Table 2).

418 During the time of regular immune response, the upregulation of PD-1 expression occurs 419 in response to T cell activation. Then interaction with PD-L1 and PD-L2 appears to deliver 420 negative signals and eventually lead to the apoptosis of activated lymphocytes (Sharpe et al., 421 2007). Several reports reveal that persistent hyperexpression of the co-inhibitory molecules 422 promotes $\mathrm{T}$ cell exhaustion with a progressive loss of their effector function. Exhausted T cells 423 express multiple inhibitory receptors, that take part in the negative immune regulation.

424 Therefore, the checkpoint inhibitors affect the host response to infection by modulating the 425 balance between effective immune defense and immune-mediated tissue injury (Fallon et al., 426 2018).

427 Microorganisms may take advantage of the inhibitory signals in order to escape immune 428 surveillance and favor chronic infection (Keir et al., 2008). Therefore, overexpression of PD429 1/PD-L1 is a major feature of chronic infections in humans (Golden-Mason et al., 2007; Day et 430 al., 2006; Boni et al., 2007). Consequently, findings in our female subgroup may also suggest 
431 that their antibacterial defense is impaired. On this basis, we are tempted to speculate that 432 women with ALD may be more than men prone to infections, that frequently complicate the 433 course of the disease (Jalan et al., 2014). The issue needs to be explored in future trials.

434 Xu et al., 2014, demonstrated that PD-1 expression on T cells was changing along 435 with the HBV infection progression and its variation was correlated with HBV virus load as well 436 as liver function. We also observed differences in the frequencies of PD-1/PD-L1 positive T and 437 B cells associated with the progression and severity of the ALD course in females (Table 3, 4, 6; 438 Figure 2-4). Therefore, the expression patterns seem to change with the disease evolution, from 439 the early stage of steatosis through alcoholic hepatitis to liver cirrhosis, and finally to liver 440 cancer, and await further exploration.

Moreover, the available body of evidence indicates that the PD-1/PD-L1 pathway can

442 impact the immune clearance of antigen-presenting cells and T lymphocytes, and promote cancer 443 development. Therefore, it has emerged as a promising new target for cancer therapy due to a 444 good treatment response seen in metastatic renal and lung carcinomas, as well as melanomas 445 (Philips \& Atkins, 2015). Whether the expansion of the PD-1/PD-L1 positive lymphocytes 446 demonstrated in our studied women with ALD is relevant in terms of the risk of neoplasm 447 development needs to be further clarified.

448 Our results are particularly noteworthy in the light of alarming findings of the recent 449 publication authored by Grant et al., 2017. The researchers reported increases in the proportion 450 of women who drink alcohol and in high-risk drinking patterns among women, as well as the 451 higher 12-month prevalence of alcohol use disorders among women.

452 Also, a recent study by Lowe et al., 2019, points to gender differences in alcohol 453 preference and indicates that inhibition of various steps in inflammasome signaling can reduce 454 alcohol consumption in females. Therefore, targeting an inflammatory cascade in ALD seems to 455 open new insights into the development of modern treatments focused on individually tailored 456 therapy.

If the results of our study are confirmed, several potential prospects emerge from them.

(1) Since gender-related disparities in regulatory immune mechanisms exist in ALD patients, there is a strong need to re-arrange the treatment regimens. immunity create an encouraging approach to the management of patients with ALD. 
462

463

464

465

466

467

468

469

470

471

472

473

474

475

476

477

478

479

480

481

482

483

484

485

486

487

488

489

490

491

492

493

494

(3) Targeting the PD-1/PD-L1 pathway seems to be helpful in amelioration of immunedysregulation and therefore requires further in-depth investigations in ALD.

Our findings should be interpreted with caution in the context of potential limitations. First, this was a single-center and a pilot study, therefore the overall sample size is relatively small. Second, we have not evaluated the changes of the PD-1/PD-L1 expression in the same individual over time, therefore, the impact of treatment effects cannot be assessed. Third, since the present study was not designed to predict the mortality of ALD in relation to the PD-1/PD-L1 expression, the relatively small number of non-survivors (only 5 persons) makes the evaluation likely biased. Fourth, alcohol consumption was self-reported in our study. As demonstrated by Stockwell \& Stirling, 1989, most people are not able to accurately assess the volume and power of a drink, so the real ethanol intake may lack precision. The impact of recall bias, as well as a deliberate misreporting of alcohol consumption also cannot be ruled out.

\section{Conclusions}

Our research adds new evidence to a limited number of studies conducted on the role of checkpoint inhibitors in alcohol abusers with ALD. The findings show that gender-related differences in the frequencies of PD-1/PD-L1 positive T and B cells in the peripheral blood exist and might potentially be related to different susceptibility to ethanol-induced liver damage in men and women. Since the upregulation of the frequencies of PD-1/PD- L1 positive lymphocytes paralleled both the severity of $\mathrm{AH}$ and liver dysfunction in females with ALD, the pathway seems to play a pivotal role in the disease progression. Results from our study may be further exploited to re-define therapeutic targets and create sex-tailored interventions for ALD treatment according to individual patient needs. Consequently, our findings represent an initial step in the exploration of ethanol- and sex-related alterations in immune cells reactivity modulated by the PD-1/PD-L1 pathway.

\section{References}

1. Yoon YH, Chen CM. National Institute on Alcohol Abuse and Alcoholism. Surveillance report \#111 Liver cirrhosis mortality in the United States: national, state, and regional trends, 2000-2015. Available at: https://pubs.niaaa.nih.gov/publications/surveillance111/Cirr15.pdf

2. National Institute on Alcohol Abuse and Alcoholism. Alcohol facts and statistics (2017). Available at: https://www.niaaa.nih.gov/alcohol-health/overview-alcoholconsumption/alcohol-facts-and-statistics. 
495 3. World Health Organization. WHO mortality database: raw data files. Geneva: World

496 Health Organization. (2018). Available at:

497 http://www.who.int/healthinfo/statistics/mortality_rawdata/en/

498

499 4. Bosetti C, Levi F, Lucchini F, Zatonski WA, Negri E, La Vecchia C. Worldwide mortality

500 from cirrhosis: an update to 2002. J Hepatol. 2007;46(5):827-39. [PMID:17336419

501 DOI: https://doi.org/10.1016/j.jhep.2007.01.025]

502

503

5. Sheron N. J Hepatol. 2016 ;64(4):957-67. [PMID:26592352; doi:

504 10.1016/j.jhep.2015.11.006.]

505

506

6. Rehm J, Samokhvalov AV, Shield KD. Global burden of alcoholic liver diseases. J Hepatol.

507 2013; 59, 160-168. [PMID: 23511777; DOI:10.1016/j.jhep.2013.03.007.]

508 7. Ndugga N, Lightbourne TG, Javaherian K, Cabezas J, Verma N, Barritt AS 4th, Bataller R. 509 Disparities between research attention and burden in liver diseases: implications on uneven 510 advances in pharmacological therapies in Europe and the USA. BMJ Open. 2017;7(3):e013620. 511 [PMID:28336739; PMCID:PMC5372160; DOI:10.1136/bmjopen-2016-013620]

512

513 8. Gao B, Tsukamoto H. Inflammation in alcoholic and nonalcoholic fatty liver disease: friend or 514 foe? Gastroenterology. 2016; 150(8): 1704-1709. [PMID: 26826669

515 doi: 10.1053/j.gastro.2016.01.025]

516

517 9. Szabo G, Saha B. Alcohol's Effect on Host Defense. Alcohol Res. 2015;37(2):159-70.

518 [PMID:26695755 PMCID:PMC4590613]

519

520

10. Molina PE, Happel KI, Zhang P, Kolls JK, Nelson S. Focus on: Alcohol and the immune

521 system. Alcohol Res Health. 2010;33(1-2):97-108. [PMID:23579940 PMCID:PMC3887500]

522

523

524

525

526

527

528

529

530

531

532

11. Louvet A, Mathurin P. Alcoholic liver disease: mechanisms of injury and targeted treatment. Nat Rev Gastroenterol Hepatol. 2015;12(4):231-42. [PMID:25782093 doi:

10.1038/nrgastro.2015.35]

12. Hernaez R, Solà E, Moreau R, Ginès P. Acute-on-chronic liver failure: an update.

Gut. 2017;66(3):541-553. [PMID:28053053 PMCID:PMC5534763 doi: 10.1136/gutjnl-2016312670]

13. Yamazaki T, Akiba H, Iwai H, Matsuda H, Aoki M, Tanno Y, Shin T, Tsuchiya H, Pardoll DM, Okumura K, Azuma M, Yagita H. Expression of programmed death 1 ligands by murine $\mathrm{T}$ 533

534 cells and APC. J Immunol. 2002;169(10):5538-45. [PMID:12421930

535

DOI:10.4049/jimmunol.169.10.5538] 
536 14. Boussiotis VA, Chatterjee P, Li L. Biochemical signaling of PD-1 on T cells and its

537 functional implications. Cancer J. 2014;20(4):265-71. [PMID:25098287 PMCID:PMC4151049

538 doi: 10.1097/PPO.0000000000000059]

539

540

541

15. Bardhan K, Anagnostou T, Boussiotis VA. The PD1:PD-L1/2 Pathway from discovery to clinical implementation. Front Immunol.2016;7:550. [PMID:28018338 PMCID:PMC5149523

542

543

544

545

546

547

548

549

550

551

552

553

554

555

556

557

558

559

560

561

562

563

564

565

566

567

568

569

570

571

572

573

574

575

576

577

578

579

580

16. Saresella M, Rainone V, Al-Daghri NM, Clerici M, Trabattoni D. The PD-1/PD-L1 pathway in human pathology. Curr Mol Med.2012;12(3):259-67. [PMID:22300137;

DOI: $10.2174 / 156652412799218903]$

17. Dinesh RK, Hahn BH, Singh RP. PD-1, gender, and autoimmunity. Autoimmun Rev. 2010;9(8):583-7. [PMID:20433954 PMCID:PMC2884990 doi: $10.1016 / j$.autrev.2010.04.003]

18. Zamani MR, Aslani S, Salmaninejad A, Javan MR, Rezaei N. PD-1/PD-L and autoimmunity: A growing relationship. Cell Immunol. 2016 ;310:27-41. [PMID:27660198 doi: 10.1016/j.cellimm.2016.09.009]

19. Whitacre CC. Sex differences in autoimmune disease. Nat Immunol. 2001;2(9):777-80. [PMID:11526384 DOI:10.1038/ni0901-777]

20. Arroyo IC, Montor JM. Non-reproductive effects of sex steroids: their immunoregulatory role. Curr Top Med Chem. 2011;11(13):1661-2. [PMID:21463256 DOI: $\underline{10.2174 / 156802611796117603]}$

21. Kasztelan-Szczerbinska B, Surdacka A, Slomka M, Rolinski J, Celinski K, Cichoz-Lach H, Madro A, Szczerbinski M. Angiogenesis-related biomarkers in patients with alcoholic liver disease: their association with liver disease complications and outcome. Mediators

Inflamm. 2014;2014:673032. [PMID:24959006. PMCID:PMC4052180

doi: $10.1155 / 2014 / 673032]$

22. Kasztelan-Szczerbińska B, Surdacka A, Celiński K, Roliński J, Zwolak A, Miącz $\underline{\mathrm{S}}$, Szczerbiński M. Prognostic Significance of the Systemic Inflammatory and Immune Balance in Alcoholic Liver Disease with a Focus on Gender-Related Differences. PLoS

One. 2015;10(6):e0128347. [PMID:26107937 PMCID:PMC4480424

doi: 10.1371/journal.pone.0128347]

23. Stickel, F., Datz, C., Hampe, J. \& Bataller, R. Pathophysiology and management of alcoholic liver disease: Update 2016. Gut Liver. 2017;11(2):173-188. [PMID:28274107

PMCID:PMC5347641 doi: 10.5009/gnl16477]

24. Saunders JB, Aasland OG, Babor TF, de la Fuente JR, Grant M. Development of the Alcohol Use Disorders Identification Test (AUDIT): WHO collaborative project on early 
581 detection of persons with harmful alcohol consumption--II. Addiction. 1993;88(6):791-804.

582 [PMID:8329970 DOI:10.1111/j.1360-0443.1993.tb02093.x.]

583

584

585

586

25. http://www.who.int/gho/alcohol/consumption_patterns/heavy_episodic_drinkers_text/en/

26. Peng Y, Qi X, Guo X. Child-Pugh versus MELD score for the assessment

587

588

589

590

591

592 of prognosis in liver cirrhosis: a systematic review and meta-analysis of observational studies. Medicine (Baltimore). 2016;95(8):e2877. [PMID:26937922 PMCID:PMC4779019 doi: 10.1097/MD.0000000000002877]

27. Ashwani K, Singal AK, Kamath PS. Model for End-stage Liver Disease. J Clin Exp Hepatol. 2013;3(1):50-60. [PMID:25755471 PMCID:PMC3940492

593

594

595 doi: $10.1016 / \mathrm{j} . j \mathrm{ceh} .2012 .11 .002]$

28. Dharel N, Bajaj JS. Definition and nomenclature of hepatic encephalopathy J Clin Exp Hepatol. 2015;5(Suppl 1):S37-41. [PMID:26041955 PMCID:PMC4442858

597 doi: $10.1016 /$ j.jceh.2014.10.001]

598

599

29. DeLong ER, DeLong DM, Clarke-Pearson D L. Comparing the areas under two or more

600

601

602

603

604

605

606

607

608 correlated receiver operating characteristic curves: a nonparametric approach. Biometrics. 1988;44(3):837-45. [PMID:3203132]

30. Schisterman EF, Perkins NJ, Liu A, Bondell H. Optimal cut-point and its corresponding Youden index to discriminate individuals using pooled blood samples.

Epidemiology. 2005;16(1):73-81. [PMID:15613948]

31. Loft S, Olesen KL, Døssing M. Increased susceptibility to liver disease in relation to alcohol consumption in women. Scand J Gastroenterol. 1987;22(10):1251-6.

609

610

611 [PMID:3433014. DOI:10.3109/00365528708996472]

32. Becker U, Deis A, Sørensen TI, Grønbaek M, Borch-Johnsen K, Müller CF, Schnohr

612 P, Jensen G. Prediction of risk of liver disease by alcohol intake, sex, and age: a prospective 613 population study. Hepatology. 1996;23(5):1025-9. [PMID:8621128.

614 DOI:10.1002/hep.510230513]

615

616

617

33. Rehm J, Sulkowska U, Mańczuk M, Boffetta P, Powles J, Popova S, Zatoński W. Alcohol accounts for a high proportion of premature mortality in central and eastern Europe. Int $J$

618

619

620

621

622

623

624

625

Epidemiol. 2007;36(2):458-67. [PMID:17251244. DOI:10.1093/ije/dyl294]

34. Farcomeni A., Ventura L. An overview of robust methods in medical research. Stat Methods Med Res. 2012;21(2):111-33. [PMID:20974666 doi: 10.1177/0962280210385865]

35. Qin G, Hotilovac L. Comparison of non-parametric confidence intervals for the area under the ROC curve of a continuous-scale diagnostic test. Stat Methods Med Res. 2008;17(2):207-21. [PMID:18426855 doi: 10.1177/0962280207087173] 
627

628

629

630

631

632

633

634

635

636

637

638

639

640

641

642

643

644

645

646

647

648

649

650

651

652

653

654

655

656

657

658

659

660

661

662

663

664

665

666

667

668

669

670

671

36. Orman ES, Odena G, Bataller R. Alcoholic liver disease: pathogenesis, management, and novel targets for therapy. J Gastroenterol Hepatol. 2013 ;28 Suppl 1:77-84. [PMID:23855300 PMCID:PMC4405238 doi:10.1111/jgh.12030]

37. Poznyak V, Rekve D. Global status report on alcohol and health 2014. World Health Organization 2014.

38. Sutti S, Bruzzì S, Albano E. The role of immune mechanisms in alcoholic and nonalcoholic steatohepatitis: a 2015 update. Expert Rev Gastroenterol Hepatol. 2016;10(2):243-53.

[PMID:26634783 doi: 10.1586/17474124.2016.1111758]

39. Riva A, Chokshi S. Immune checkpoint receptors: homeostatic regulators of immunity. Hepatol Int. 2018;12(3):223-236. [PMID:29740793 PMCID:PMC5999155 doi:10.1007/s12072018-9867-9]

40. Pardoll DM. The blockade of immune checkpoints in cancer immunotherapy. Nat Rev Cancer. 2012;12(4):252-64. [PMID:22437870 PMCID:PMC4856023 doi: 10.1038/nrc3239]

41. Moir S, Fauci AS. B-cell exhaustion in HIV infection: the role of immune activation. Curr Opin HIV AIDS. 2014;9(5):472-7. [PMID:25023621 doi:10.1097/COH.0000000000000092]

42. Boliar S, Murphy MK, Tran TC, Carnathan DG, Armstrong WS, Silvestri G, Derdeyn CA. B-lymphocyte dysfunction in chronic HIV-1 infection does not prevent cross-clade neutralization breadth. J Virol. 2012;86(15):8031-40. [PMID:22623771 PMCID:PMC3421653 doi: 10.1128/JVI.00771-12]

43. Huang R, Wu, H, Liu, Y, Xiong Y, Xia J, Pan Z, Wang G, Sun Z, Yan X, Chen J, Zhang Z, $\mathrm{Wu}$ C. B cells may play a pathological role in hepatic inflammation in chronic liver diseases. Int J Clin Exp Pathol.2016;9(3):3630-3635.

44. Husby G, Skrede S, Blomhoff JP, Jacobsen CD, Berg K, Gjone E. Serum Immunoglobulins and organ nonspecific antibodies in diseases of the liver. Scand J Gastroenterol. 1977;12(3):297304. [PMID:866991 DOI:10.3109/00365527709180931]

45. Tomasi TB, Tisdale WA. Serum gamma-globulins in acute and chronic liver diseases. Nature. 1964;201:834-5. [PMID:14161227 DOI:10.1038/201834a0]

46. Matos LC, Batista P, Monteiro N, Ribeiro J, Cipriano MA, Henriques P, Girão F, Carvalho A. Lymphocyte subsets in alcoholic liver disease. World J Hepatol. 2013 Feb 27;5(2):46-55. doi: 10.4254/wjh.v5.i2.46. PMID: 23646229; PMCID: PMC3642723.

47. Zhang H, Meadows GG. Chronic alcohol consumption in mice increases the proportion of peripheral memory T cells by homeostatic proliferation. J Leukoc Biol. 2005 Nov;78(5):107080. doi: 10.1189/jlb.0605317. Erratum in: J Leukoc Biol. 2008 Mar;83(3):797. PMID: 16260584. 
672 48. Li S, Tan HY, Wang N, Feng Y, Wang X, Feng Y. Recent Insights Into the Role of Immune

673 Cells in Alcoholic Liver Disease. Front Immunol. 2019;10:1328. Published 2019 Jun 12.

674 doi:10.3389/fimmu.2019.01328

675

676 49. Parra D, Takizawa F, Sunyer JO. Evolution of B cell immunity. Annu Rev Anim Biosci.

677 2013 Jan;1:65-97. doi: 10.1146/annurev-animal-031412-103651. PMID: 25340015; PMCID:

678 PMC4203447.

679

680

50. Andrade MC, Albernaz MJ, Araújo MS, Santos BP, Teixeira-Carvalho A, Faria AM,

681

682

683

684

685

686

687

688

689

690

691

692

693

694

695

696

697

698

699

700

701

702

703

704

705

706

707

708

709

710

711

712

713

714

Martins-Filho OA. Short-term administration of ethanol in mice deviates antigen presentation activity towards B cells. Scand J Immunol. 2009 Sep;70(3):226-37. doi: 10.1111/j.13653083.2009.02289.x. PMID: 19703012.)

51. Wu Y, Ju Q, Jia K, Yu J, Shi H, Wu H, Jiang M. Correlation between sex and efficacy of immune checkpoint inhibitors (PD-1 and CTLA-4 inhibitors. Int J Cancer. 2018;143(1):45-51. [PMID:29424425 doi: 10.1002/ijc.31301]

52. Capone I, Marchetti P, Ascierto PA, Malorni W, Gabriele L. Sexual Dimorphism of Immune Responses: A New Perspective in Cancer Immunotherapy. Front Immunol. 2018;9:552. [PMID:29619026. PMCID:PMC5871673 doi:10.3389/fimmu.2018.00552]

53. Klein SL, Flanagan KL. Sex differences in immune responses. Nat Rev Immunol. 2016;16(10):626-38. [PMID:27546235 doi: 10.1038/nri.2016.90]

54. Chou SP. Sex differences in morbidity among respondents classified as alcohol abusers and/or dependent: results of a national survey. Addiction. 1994;89(1):87-93. [PMID:8148748. DOI: $10.1111 / \mathrm{j} .1360-0443.1994 . t b 00853 . \mathrm{x}]$

55. Greenfield SF. Women and alcohol use disorders. Harv Rev Psychiatry. 2002;10(2):76-85. [PMID:11897748 DOI:10.1080/10673220216212]

56. Liang SC, Latchman YE, Buhlmann JE, Tomczak MF, Horwitz BH, Freeman GJ, Sharpe AH. Regulation of PD-1, PD-L1, and PD-L2 expression during normal and autoimmune responses. Eur J Immunol. 2003;33(10):2706-16. [PMID:14515254 DOI:10.1002/eji.200324228]

57. Markwick LJ, Riva A, Ryan JM, Cooksley H, Palma E, Tranah TH, Manakkat Vijay GK, Vergis N, Thursz M, Evans A, Wright G, Tarff S, O'Grady J, Williams R, Shawcross DL, Chokshi S. Blockade of PD1 and TIM3 restores innate and adaptive immunity in patients with acute alcoholic hepatitis. Gastroenterology. 2015;148(3):590-602.e10. [PMID:25479137 doi: 10.1053/j.gastro.2014.11.041]

58. Jia Y, Zhao Y, Li C, Shao R. The Expression of Programmed Death-1 on CD4+ and CD8+ T Lymphocytes in Patients with Type 2 Diabetes and Severe Sepsis. PLoS

Peer] reviewing PDF | (2020:06:49751:1:2:NEW 8 Nov 2020) 
715 One. 2016;11(7):e0159383. [PMID:27459386 PMCID:PMC4961422

716 doi:10.1371/journal.pone.0159383]

717

718

719

720

721

722

723

724

725

726

727

728

729

730

731

732

733

734

735

736

737

738

739

740

741

742

743

744

745

746

747

748

749

750

751

752

753

754

755

756

757

758

759

760

59. Zhang Y, Li J, Lou J, Zhou Y, Bo L, Zhu J, Zhu K, Wan X, Cai Z, Deng X. Upregulation of programmed death-1 on T cells and programmed death ligand-1 on monocytes in septic shock patients. Crit Care. 2011;15(1):R70. [PMID:21349174 PMCID:PMC3222003 doi:10.1186/cc10059]

60. Naveau S, Chollet-Martin S, Dharancy S, Mathurin P, Jouet P, Piquet MA, Davion T, Oberti F, Broët P, Emilie D; Foie-Alcool group of the Association Française pour l'Etude du Foie. A double-blind randomized controlled trial of infliximab associated with prednisolone in acute alcoholic hepatitis. Hepatology. 2004;39(5):1390-7. [PMID:15122768. DOI:10.1002/hep.20206]

61. Liu MF, Weng, CT, Weng MY. Variable increased expression of program death-1 and program death-1 ligands on peripheral mononuclear cells is not impaired in patients with systemic lupus erythematosus. J Biomed Biotechnol. 2009;2009:406136. [PMID:19759858 PMCID:PMC2744882 doi: 10.1155/2009/406136]

62. Sharpe AH, Wherry EJ, Ahmed R, Freeman GJ. The function of programmed cell death 1 and its ligands in regulating autoimmunity and infection. Nat Immunol. 2007;8(3):239-45. [PMID:17304234 DOI:10.1038/ni1443]

63. Fallon EA, Biron-Girard BM, Chung CS, Lomas-Neira J, Heffernan DS, Monaghan SF, Ayala A. A novel role for coinhibitory receptors/checkpoint proteins in the immunopathology of sepsis. J Leukoc Biol. 2018 Feb 2. [PMID:29393983 PMCID:PMC6314914 doi:10.1002/JLB.2MIR0917-377R]

64. Keir ME, Butte MJ, Freeman GJ, Sharpe AH. PD-1 and its ligands in tolerance and immunity. Ann Rev Immunol. 2008;26:677-704. [PMID:18173375 doi:10.1146/annurev.immunol.26.021607.090331]

65. Golden-Mason L, Palmer B, Klarquist J, Mengshol JA, Castelblanco N, Rosen HR. Upregulation of PD-1 expressi, on on circulating and intrahepatic hepatitis $\mathrm{C}$ virus-specific CD8+ T cells associated with reversible immune dysfunction. $J$ Virol. 2007;81(17):9249-58. [PMID:17567698 PMCID:PMC1951397 DOI:10.1128/JVI.00409-07]

66. Day CL, Kaufmann DE, Kiepiela P, Brown JA, Moodley ES, Reddy S, Mackey EW, Miller JD, Leslie AJ, DePierres C, Mncube Z, Duraiswamy J, Zhu B, Eichbaum Q, Altfeld M, Wherry EJ, Coovadia HM, Goulder PJ, Klenerman P, Ahmed R, Freeman GJ, Walker BD. PD-1 expression on HIV-specific T cells is associated with T-cell exhaustion and disease progression. Nature. 2006;443(7109):350-4. [PMID:16921384. DOI:10.1038/nature05115]

67. Boni C, Fisicaro P, Valdatta C, Amadei B, Di Vincenzo P, Giuberti T, Laccabue D, Zerbini A, Cavalli A, Missale G, Bertoletti A, Ferrari C. Characterization of hepatitis B virus (HBV)specific T-cell dysfunction in chronic HBV infection. $J$ Virol. 2007;81(8):4215-25.

[PMID:17287266 PMCID:PMC1866111 DOI:10.1128/JVI.02844-06]

Peer) reviewing PDF | (2020:06:49751:1:2:NEW 8 Nov 2020) 
761

762

763

764

765

766

767

768

769

770

771

772

773

774

775

776

777

778

779

780

781

782

783

784

785

786

787

788

789

790
68. Jalan R, Fernandez J, Wiest R, Schnabl B, Moreau R, Angeli P, Stadlbauer V, Gustot T, Bernardi M, Canton R, Albillos A, Lammert F, Wilmer A, Mookerjee R, Vila J, GarciaMartinez R, Wendon J, Such J, Cordoba J, Sanyal A, Garcia-Tsao G, Arroyo V, Burroughs A, Ginès P. Bacterial infections in cirrhosis: a position statement based on the EASL Special Conference 2013. J Hepatol. 2014;60(6):1310-24. [PMID:24530646 doi:10.1016/j.jhep.2014.01.024]

69. Xu P, Chen YJ, Chen H, Zhu XY, Song HF, Cao LJ, Wang XF. The Expression of Programmed Death-1 in Circulating CD4+ and CD8+ T Cells during Hepatitis B Virus Infection Progression and Its Correlation with Clinical Baseline Characteristics. Gut Liver. 2014;8(2):18695. [PMID:24672661 PMCID:PMC3964270 doi:10.5009/gnl.2014.8.2.186]

70. Philips GK, Atkins, M. Therapeutic uses of anti-PD-1 and anti-PD-L1 antibodies. Int Immunol. 2015;27(1):39-46. [PMID:25323844 doi: 10.1093/intimm/dxu095]

71. Grant BF, Chou SP, Saha TD, Pickering RP, Kerridge BT, Ruan WJ, Huang B, Jung J, Zhang H, Fan A, Hasin DS. Prevalence of 12-month alcohol use, high-risk drinking, and DSM-IV alcohol use disorder in the United States, 2001-2002 to 2012-2013: results from the national epidemiologic survey on alcohol and related conditions. JAMA

Psychiatry. 2017;74(9):911-923. [PMID:28793133 PMCID:PMC5710229

doi:10.1001/jamapsychiatry.2017.2161]

72. Lowe P, Cho Y, Tornai D, Coban S, Catalano D, Szabo G. Inhibition of inflammasome signaling cascade reduces alcohol consumption in female but not male mice. Alcohol Clin Exp Res. 2019. [PMID:31854009 doi: 10.1111/acer.14272]

73. Stockwell T, Stirling, L. Estimating alcohol content of drinks: common errors in applying the unit system. BMJ. 1989;298(6673):571-2. [PMID:2495119. PMCID:PMC1835945.

DOI: $10.1136 /$ bmj.298.6673.571-a] 
Figure 1

Comparison of the frequencies (\%) of PD-1 and PD-L1 positive T and B cells in ALD females versus female controls $(* p<0.05)$. 


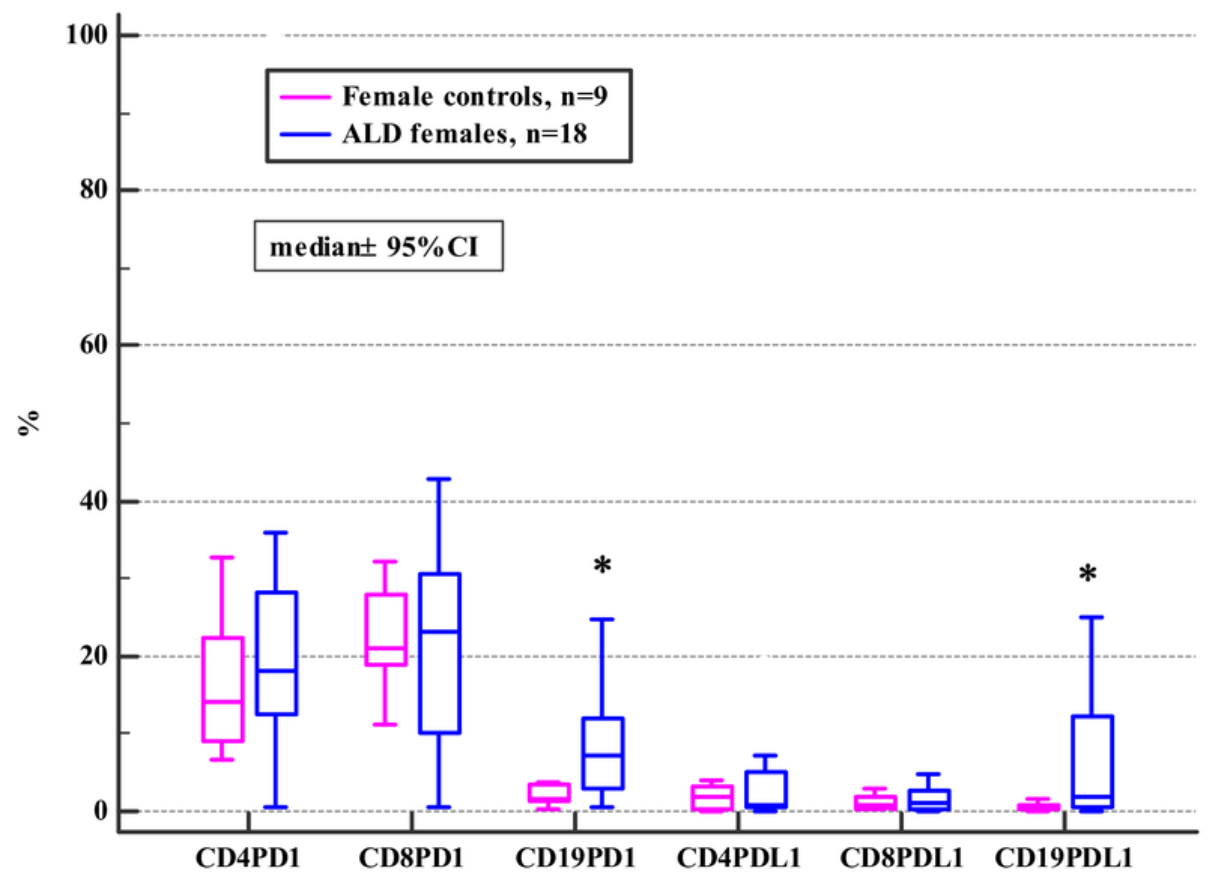


Figure 2

Comparison of the frequencies (\%) of PD-1 and PDL-1 positive T and B cells in ALD males and females with MELD $>20(* p<0.05)$. 


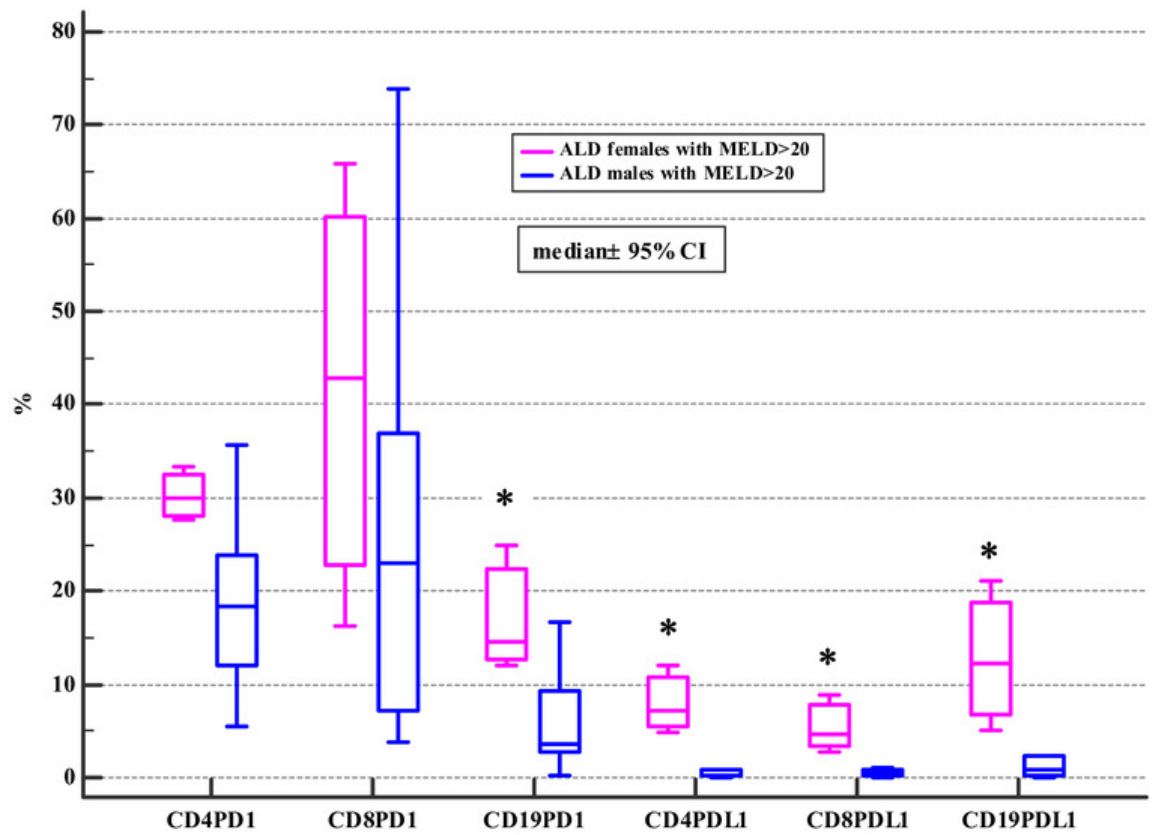


Figure 3

Comparison of the frequencies (\%) of PD-1 and PDL-1 positive T and B cells in ALD males and females with mDF $>32(* p<0.05)$. 


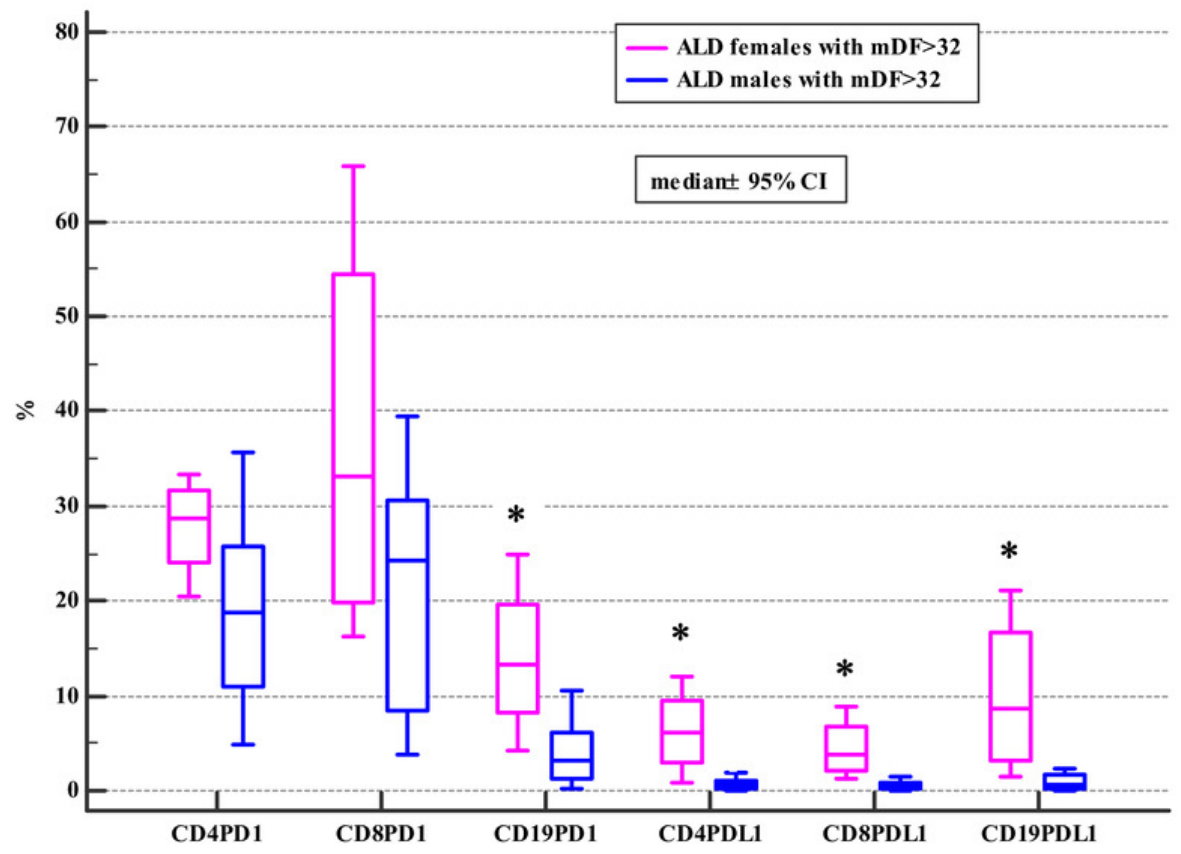


Figure 4

Comparison of the frequencies (\%) of PD-1 and PD-L1 positive T and B cells in ALD patients with CTP class C based on patients' gender $(* p<0.05)$. 


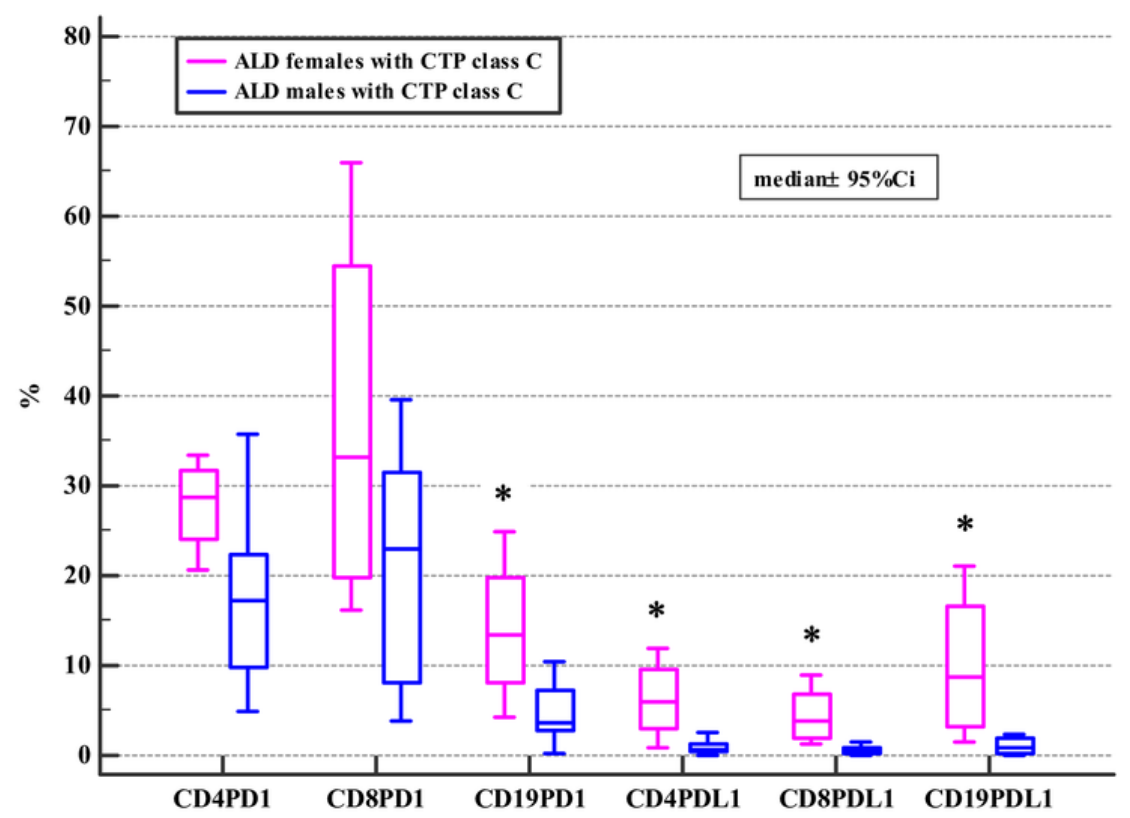




\section{Table $\mathbf{1}$ (on next page)}

Demografic and laboratory data of the studied group. *

* Alb- albumin (normal range [NR] 3.2- 4.8); ALD- alcohol-related liver disease; ALT- alanine aminotransferase (NR < 31); ALP- alkaline phosphatase (NR 45-129); AST- aspartate aminotransferase (NR < 34); Bil- bilirubin (NR 0.3-1.2); Crea- creatinine (NR 0.5-1.1); CRPCreactive protein (NR 0.0-5.0); CTP- Child-Turcotte- Pugh score; EV- esophageal varices; GGTgamma-glutamyl transpeptidase (NR <50.0); HE- hepatic encephalopathy; Hgb- hemoglobin (NR 14.0-18.0); INR International Normalized Ratio (NR 0.8-1.2); mDF- the Maddrey's Discriminant Function; MELD- Model for End-Stage Liver Disease; NEUT- neutrophils (NR 1.8-7.7); NLR- neutrophil to lymphocyte ratio; p- significancelevel, PLT- platelets (NR 130400); RBC- red blood cells (NR 4.5-6.1); WBC- white blood cells (NR 4.8-10.8) 


\begin{tabular}{|c|c|c|c|c|c|c|c|c|c|c|}
\hline \multirow{3}{*}{ Variable } & \multicolumn{4}{|c|}{ ALD group } & \multirow{3}{*}{$\mathrm{p}$} & \multicolumn{4}{|c|}{ Controls } & \multirow{3}{*}{$\mathrm{p}$} \\
\hline & \multicolumn{2}{|c|}{ Males $(n=38)$} & \multicolumn{2}{|c|}{ Females $(n=18)$} & & \multicolumn{2}{|c|}{ Males $(n=16)$} & \multicolumn{2}{|c|}{ Females $(n=9)$} & \\
\hline & Median & $\begin{array}{c}5 \text { - } 95 \\
\text { percentiles }\end{array}$ & Median & $\begin{array}{c}5-95 \\
\text { percentiles }\end{array}$ & & Median & $\begin{array}{c}5-95 \\
\text { percentiles }\end{array}$ & Median & $\begin{array}{c}5-95 \\
\text { percentiles }\end{array}$ & \\
\hline Age /years/ & 49.00 & $33.00-64.00$ & 51.50 & $25.00-67,00$ & 0.62 & 42,50 & $29,00-53,00$ & 37.00 & $28.00-72.00$ & 0.65 \\
\hline ALT IU/L & 48.50 & $19.40-250.00$ & 39.50 & $21.00-240.00$ & 0.33 & 27.50 & $21.30-30.70$ & 28.00 & $22.00-30.00$ & 0.80 \\
\hline AST IU/L & 111.00 & $41.85-503.45$ & 102.50 & $39.00-261.00$ & 0.40 & 24.50 & $20.60-27.40$ & 26.00 & $22.00-28.00$ & 0.26 \\
\hline ALP IU/L & 140.00 & $75.00-492.15$ & 136.00 & $71.05-348.70$ & 0.80 & 91.50 & $73.60-102.00$ & 98.00 & $\begin{array}{l}77.00- \\
111.00\end{array}$ & 0.26 \\
\hline GTP IU/L & 390.00 & $\begin{array}{c}60.80- \\
2394.15\end{array}$ & 410.50 & $92.60-521.80$ & 0.39 & 10.50 & $9.00-12.70$ & 10.00 & $9.00-12.00$ & 0.72 \\
\hline Bil mg/dL & 3.40 & $1.00-19.50$ & 2.05 & $0.60-28.10$ & 0.69 & 0.80 & $0.50-1.00$ & 0.70 & $0.30-0.90$ & 0.17 \\
\hline Alb g/dL & 2.96 & $1.93-4.02$ & 3.28 & $2.25-4.64$ & 0.19 & 4.07 & $3.87-4.23$ & 4.11 & $3.79-4.23$ & 0.93 \\
\hline INR & 1.41 & $0.93-2.67$ & 1.43 & $0.75-2.44$ & 0.71 & 0.90 & $0.90-1.10$ & 1.00 & $0.90-1.10$ & 0.66 \\
\hline Crea mg/dL & 0.70 & $0.44-1.73$ & 0.60 & $0.44-2.22$ & 0.26 & 0.80 & $0.60-1.07$ & 0.75 & $0.60-1.00$ & 0.55 \\
\hline CRP mg/L & 21.71 & $1.75-81.75$ & 26.40 & $0.57-122.58$ & 0.73 & 1.84 & $0.65-3.41$ & 1.97 & $0.98-3.12$ & 0.71 \\
\hline $\begin{array}{l}\text { WBC } \times 10^{3} \\
\text { cells } / \mu \mathrm{L}\end{array}$ & 6.88 & $3.43-17.16$ & 7.905 & $3.262-23.580$ & 0.69 & 5.15 & $4.30-6.88$ & 5.46 & $4.51-6.21$ & 0.59 \\
\hline $\begin{array}{l}\text { NEUT } \times 10^{3} \\
\text { cells } / \mu \mathrm{L}\end{array}$ & 4.59 & $2.12-15.23$ & 4.88 & $1.52-20.28$ & 0.74 & 3.18 & $2.78-4.36$ & 3.41 & $2.68-3.80$ & 0.63 \\
\hline NLR & 4.33 & $1.64-14.62$ & 3.64 & $1.45-22.08$ & 0.51 & 2.21 & $1.80-2.51$ & 1.98 & $1.61-2.30$ & 0.43 \\
\hline $\begin{array}{l}\mathrm{PLT} \times 10^{3} \\
\text { cells/ } \mu \mathrm{L}\end{array}$ & 128.00 & $46.15-236.15$ & 155.00 & $54.00-412.20$ & 0.09 & 312.50 & $258.00-354.60$ & 291.00 & $\begin{array}{l}233.00- \\
333.00\end{array}$ & 0.09 \\
\hline $\begin{array}{l}\text { RBC } \times 10^{6} \\
\text { cells/ } \mu \mathrm{L}\end{array}$ & 3.47 & $2.53-4.75$ & 3.80 & $2.73-248.69$ & 0.24 & 5.13 & $4.81-5.39$ & 4.23 & $4.11-5.00$ & $<0.001$ \\
\hline HGB g/dL & 11.50 & $8.53-15.27$ & 12.25 & $8.94-16.86$ & 0.17 & 15.80 & $14.83-16.27$ & 12.90 & $12.30-13.10$ & $<0.001$ \\
\hline MELD & 16.00 & $6.45-30.55$ & 14.00 & $6.40-34.60$ & 0.39 & & & & & \\
\hline $\mathrm{mDF}$ & 18.94 & $0.91-97.706$ & 15.94 & $0.29-100.02$ & 0.48 & & & & & \\
\hline \multicolumn{5}{|l|}{ CTP class } & \multirow{4}{*}{0.66} & & & & & \\
\hline A & \multirow{2}{*}{\multicolumn{2}{|c|}{$\begin{array}{c}9(23.68 \%) \\
16(42.10 \%)\end{array}$}} & \multicolumn{2}{|c|}{$\begin{array}{l}5(27.78 \%) \\
9(5000 \%)\end{array}$} & & & & & & \\
\hline B & & & \multirow{2}{*}{\multicolumn{2}{|c|}{$4(22.22 \%)$}} & & & & & & \\
\hline C & \multicolumn{2}{|c|}{$13(34.21 \%)$} & & & & & & & & \\
\hline \multicolumn{11}{|l|}{$\begin{array}{l}\text { ALD } \\
\text { complications }\end{array}$} \\
\hline ascites & \multicolumn{2}{|c|}{$18(47.37 \%)$} & \multicolumn{2}{|c|}{$9(50.00 \%)$} & 0.79 & & & & & \\
\hline $\mathrm{HE}$ & \multicolumn{2}{|c|}{$5(13.16 \%)$} & \multicolumn{2}{|r|}{$1(5.55 \%)$} & 0.41 & & & & & \\
\hline EV & \multirow{2}{*}{\multicolumn{2}{|c|}{$\frac{20(52.63 \%)}{4(10.53 \%)}$}} & \multicolumn{2}{|c|}{$\begin{array}{c}9(50.00 \%) \\
1(5.55 \%)\end{array}$} & 0.98 & & & & & \\
\hline non-survival & & & & $1(5.55 \%)$ & 0.56 & & & & & \\
\hline
\end{tabular}




\section{Table 2 (on next page)}

Comparison of the frequencies (\%) of PD-1/PD-L1 positive T and B lymphocytes inALD and controls based on patients' gender ('Mann-Whitney test).*

*p1- ALD males vs ALD females; p2- female controls vs male controls; p3- ALD males vs male controls; p4- ALD females vs female controls 


\begin{tabular}{|c|c|c|c|c|c|c|c|c|c|c|c|c|}
\hline \multirow{3}{*}{$\begin{array}{l}\text { Variabl } \\
\text { e }\end{array}$} & \multicolumn{4}{|c|}{ ALD group } & \multirow[b]{3}{*}{$\mathrm{p} 1^{*}$} & \multicolumn{4}{|c|}{ Controls } & \multirow[b]{3}{*}{$\mathbf{p 2}^{*}$} & \multirow[b]{3}{*}{ p3* } & \multirow[b]{3}{*}{$\mathrm{p} 4^{*}$} \\
\hline & \multicolumn{2}{|c|}{ Males $(n=38)$} & \multicolumn{2}{|c|}{ Females $(n=18)$} & & \multicolumn{2}{|c|}{ Males $(n=16)$} & \multicolumn{2}{|c|}{ Females $(n=9)$} & & & \\
\hline & Median & $\begin{array}{c}5-95 \\
\text { percentile }\end{array}$ & Median & $\begin{array}{c}5-95 \\
\text { Percentile }\end{array}$ & & Median & $\begin{array}{c}5-95 \\
\text { Percentile }\end{array}$ & Median & $\begin{array}{c}5-95 \\
\text { Percentile }\end{array}$ & & & \\
\hline \multicolumn{13}{|c|}{ PD-1 positive cell subsets } \\
\hline CD4+ & 18.44 & $1.83-3.28$ & 18.07 & $1.43-4.03$ & 0.73 & 21.07 & $8.40-9.64$ & 14.20 & $6.55-30.67$ & 0.17 & 0.18 & 0.60 \\
\hline CD8+ & 19.40 & $2.68-6.57$ & 23.06 & $0.67-6.70$ & 0.99 & 25.57 & $7.55-7.51$ & 21.11 & $\begin{array}{c}11.28- \\
43.08\end{array}$ & 0.68 & 0.22 & 0.63 \\
\hline CD19+ & 3.27 & $0.36-4.20$ & 7.08 & $0.69-0.76$ & 0.02 & 2.54 & $0.78-9.39$ & 1.66 & $0.35-14.70$ & 0.47 & 0.59 & 0.04 \\
\hline \multicolumn{13}{|c|}{ PD-L1 positive cell subsets } \\
\hline CD4+ & 0.65 & $0.04-2.76$ & 0.90 & $0.09-8.04$ & 0.04 & 1.06 & $0.26-5.10$ & 1.83 & $0.10-4.03$ & 0.80 & 0.09 & 0.44 \\
\hline CD8+ & 0.44 & $0.03-1.66$ & 1.14 & $0.02-7.21$ & 0.02 & 0.97 & $0.13-2.43$ & 0.89 & $0.18-2.88$ & 1.00 & 0.07 & 0.63 \\
\hline CD19+ & 0.71 & $0.01-6.40$ & 1.99 & $0.01-8.88$ & 0.04 & 0.69 & $0.25-8.77$ & 0.45 & $0.07-1.52$ & 0.16 & 0.62 & 0.03 \\
\hline
\end{tabular}




\section{Table 3 (on next page)}

Comparison of the frequencies (\%) of PD-1 and PD-L1 positive T and B cells in ALD patients with MELD>20 and controls based on patients' gender ('Mann-Whitney test).*

*p1- ALD males with MELD>20 vs ALD females with MELD>20; p2- ALD males with MELD>20 vs male controls; P3 ALD females with MELD>20 vs female controls 


\begin{tabular}{|c|c|c|c|c|c|c|c|c|c|c|c|}
\hline \multirow[b]{3}{*}{ Variable } & \multicolumn{4}{|c|}{ ALD + MELD>20 } & \multirow[b]{3}{*}{$\mathrm{p} 1^{\mathrm{a}}$} & \multicolumn{4}{|c|}{ Controls } & \multirow[b]{3}{*}{$\mathrm{p}^{\mathrm{a}}$} & \multirow[b]{3}{*}{ p3a } \\
\hline & \multicolumn{2}{|c|}{ Males $(n=10)$} & \multicolumn{2}{|c|}{ Females $(n=3)$} & & \multicolumn{2}{|c|}{ Males $(n=16)$} & \multicolumn{2}{|c|}{ Females $(n=9)$} & & \\
\hline & Median & $\begin{array}{c}\text { 5-95 } \\
\text { Percentiles }\end{array}$ & Median & $\begin{array}{c}\text { 5-95 } \\
\text { Percentiles }\end{array}$ & & Median & $\begin{array}{c}\text { 5-95 } \\
\text { Percentiles }\end{array}$ & Median & $\begin{array}{c}5-95 \\
\text { Percentiles }\end{array}$ & & \\
\hline \multicolumn{12}{|c|}{ PD-1 positive cell subsets } \\
\hline CD4+ & 18.29 & $5.49-35.77$ & 29.88 & $27.60-33.45$ & 0.17 & 21.07 & $8.40-39.64$ & 14.20 & $6.55-32.70$ & 0,48 & 0.10 \\
\hline CD8+ & 22.99 & $3.90-73.94$ & 42.91 & $16.19-65.89$ & 0.29 & 25.57 & $7.55-37.51$ & 21.11 & $11.28-43.08$ & 0,52 & 0.48 \\
\hline CD19+ & 3.53 & $0.12-16.64$ & 14.62 & $12.07-24.84$ & 0.02 & 2.54 & $0.78-19.39$ & 1.66 & $0.35-14.67$ & 0,42 & 0.04 \\
\hline \multicolumn{12}{|c|}{ PD-L1 positive cell subsets } \\
\hline CD4+ & 0.74 & $0.01-2.40$ & 7.18 & $4.93-11.94$ & $<0.01$ & 1.06 & $0.26-5.10$ & 1.83 & $0.10-4.03$ & 0,11 & $<0.01$ \\
\hline CD8+ & 0.45 & $0.07-1.15$ & 4.71 & $2.83-8.88$ & 0.01 & 0.97 & $0.13-2.45$ & 0.89 & $0.15-2.88$ & 0,09 & 0.02 \\
\hline CD19+ & 0.74 & $0.01-7.48$ & 12.20 & $5.06-21.01$ & 0.03 & 0.69 & $0.25-8.77$ & 0.45 & $0.01-1.52$ & 0,67 & $<0.01$ \\
\hline
\end{tabular}




\section{Table 4 (on next page)}

Comparison of the frequencies (\%) of PD-1 and PD-L1 positive T and B cells in ALD patients with $\mathrm{mDF}>32$ and controls based on patients' gender ('Mann-Whitney test).*

* p1- ALD males with mDF $>32$ vs ALD females with $m D F>32$; 22 - ALD males with $m D F>32$ vs male controls; p3 ALD females with mDF>32 vs female controls 


\begin{tabular}{|c|c|c|c|c|c|c|c|c|c|c|c|}
\hline \multirow{3}{*}{ Variable } & \multicolumn{4}{|c|}{$A L D+m D F>32$} & \multirow{3}{*}{$\mathrm{p} 1^{\mathrm{a}}$} & \multicolumn{4}{|c|}{ Controls } & \multirow[b]{3}{*}{$\mathrm{p}^{\mathrm{a}}$} & \multirow{3}{*}{ p3a } \\
\hline & \multicolumn{2}{|c|}{ Males $(n=13)$} & \multicolumn{2}{|c|}{ Females $(n=4)$} & & \multicolumn{2}{|c|}{ Males $(n=16)$} & \multicolumn{2}{|c|}{ Females $(n=9)$} & & \\
\hline & Median & \begin{tabular}{|c|}
$5-95$ \\
Percentiles
\end{tabular} & Median & $\begin{array}{c}5-95 \\
\text { Percentiles }\end{array}$ & & Median & $\begin{array}{c}5-95 \\
\text { Percentiles }\end{array}$ & Median & $\begin{array}{c}5-95 \\
\text { Percentiles }\end{array}$ & & \\
\hline \multicolumn{12}{|c|}{ PD-1 positive cell subsets } \\
\hline CD4+ & 18.88 & $4.94-35.50$ & 28.74 & $\begin{array}{c}20.54- \\
33.45\end{array}$ & 0.20 & 21.07 & $8.40-39.64$ & 14.20 & $\begin{array}{c}6.55- \\
2.70 \\
\end{array}$ & 0.50 & 0.07 \\
\hline CD8+ & 24.19 & $4.30-68.71$ & 33.24 & $\begin{array}{c}16.19- \\
65.89 \\
\end{array}$ & 0.35 & 25.57 & $7.55-37.51$ & 21.11 & $\begin{array}{c}11.28- \\
3.08 \\
\end{array}$ & 0.56 & 0.50 \\
\hline CD19+ & 3.21 & $0.21-15.73$ & 13.34 & $4.22-24.84$ & 0.03 & 2.54 & $0.78-19.39$ & 1.66 & $\begin{array}{c}0.35- \\
4.67\end{array}$ & 0.75 & 0.02 \\
\hline \multicolumn{12}{|c|}{ PD-L1 positive cell subsets } \\
\hline CD4+ & 0.73 & $0.09-2.45$ & 6.05 & $0.83-11.94$ & 0.01 & 1.06 & $0.26-5.10$ & 1.83 & $\begin{array}{c}0.10- \\
4.03\end{array}$ & 0,12 & 0.05 \\
\hline CD8+ & 0.43 & $0.07-1.49$ & 3.77 & $1.20-8.88$ & $<0.01$ & 0.97 & $0.13-2.45$ & 0.89 & $\begin{array}{c}0.15- \\
2.88 \\
\end{array}$ & 0,10 & 0.03 \\
\hline CD19+ & 0.54 & $0.01-7.43$ & 8.63 & $1.47-21.01$ & 0.02 & 0.69 & $0.25-8.77$ & 0.45 & $\begin{array}{c}0.01- \\
1.52 \\
\end{array}$ & 0,66 & 0.01 \\
\hline
\end{tabular}




\section{Table 5 (on next page)}

Correlations of the frequencies (\%) of PD-1 and PD-L1 positive lymphocytes with conventional markers of inflammation in ALD and control groups (Rho- Spearman rank correlation coefficient).*

*CRP- C-reactive protein; NEUT- neutrophils; NLR- neutrophil to lymphocyte ratio; WBC- white blood cells; p- significancelevel; Rho- Spearman rank correlation coefficient 


\begin{tabular}{|c|c|c|c|c|c|c|c|c|c|}
\hline \multirow[t]{2}{*}{ Variable } & & \multicolumn{4}{|c|}{ ALD group $(n=56)$} & \multicolumn{4}{|c|}{ Cotrols $(n=25)$} \\
\hline & & CRP & NEU & NLR & WBC & CRP & NEU & NLR & WBC \\
\hline \multicolumn{10}{|c|}{ PD-1 positive cell subsets } \\
\hline CD4+ & $\begin{array}{r}\text { Rho } \\
P\end{array}$ & $\begin{array}{l}0.05 \\
0.73\end{array}$ & $\begin{array}{l}0.19 \\
0.17\end{array}$ & $\begin{array}{l}0.14 \\
0.30\end{array}$ & $\begin{array}{l}0.22 \\
0.10\end{array}$ & $\begin{array}{l}0,02 \\
0,90\end{array}$ & $\begin{array}{l}0,05 \\
0,80\end{array}$ & $\begin{array}{l}0,10 \\
0,64\end{array}$ & $\begin{array}{c}-0,03 \\
0,87\end{array}$ \\
\hline CD8+ & $\begin{array}{r}\text { Rho } \\
P\end{array}$ & $\begin{array}{l}0.08 \\
0.59\end{array}$ & $\begin{array}{l}0.11 \\
0.42\end{array}$ & $\begin{array}{l}0.10 \\
0.45\end{array}$ & $\begin{array}{l}0.14 \\
0.29\end{array}$ & $\begin{array}{c}-0,29 \\
0,16\end{array}$ & $\begin{array}{l}0,18 \\
0,40\end{array}$ & $\begin{array}{l}0,20 \\
0,32\end{array}$ & $\begin{array}{l}0,07 \\
0,73\end{array}$ \\
\hline CD19+ & $\begin{array}{r}\text { Rho } \\
P\end{array}$ & $\begin{array}{l}0.18 \\
0.20\end{array}$ & $\begin{array}{l}0.27 \\
0.04\end{array}$ & $\begin{array}{c}0.161 \\
0.24\end{array}$ & $\begin{array}{l}0.31 \\
0.02\end{array}$ & $\begin{array}{l}0,18 \\
0,38\end{array}$ & $\begin{array}{c}-0,004 \\
0,98\end{array}$ & $\begin{array}{l}0,28 \\
0,18\end{array}$ & $\begin{array}{c}-0,14 \\
0,50\end{array}$ \\
\hline \multicolumn{10}{|c|}{ PD-L1 positive cell subsets } \\
\hline CD4+ & $\begin{array}{r}\text { Rho } \\
P\end{array}$ & $\begin{array}{l}0.21 \\
0.14\end{array}$ & $\begin{array}{l}0.28 \\
0.04\end{array}$ & $\begin{array}{l}0.21 \\
0.12\end{array}$ & $\begin{array}{l}0.27 \\
0.04\end{array}$ & $\begin{array}{c}-0,019 \\
0,93\end{array}$ & $\begin{array}{c}-0,003 \\
0,98\end{array}$ & $\begin{array}{c}-0,01 \\
0,94\end{array}$ & $\begin{array}{c}-0,06 \\
0,77\end{array}$ \\
\hline CD8+ & $\begin{array}{r}\text { Rho } \\
P\end{array}$ & $\begin{array}{l}0.19 \\
0.18\end{array}$ & $\begin{array}{l}0.24 \\
0.08\end{array}$ & $\begin{array}{l}0.23 \\
0.09\end{array}$ & $\begin{array}{l}0.22 \\
0.11\end{array}$ & $\begin{array}{l}0,05 \\
0,79\end{array}$ & $\begin{array}{c}-0,03 \\
0,88\end{array}$ & $\begin{array}{l}0,06 \\
0,76\end{array}$ & $\begin{array}{c}-0,13 \\
0,53\end{array}$ \\
\hline CD19+ & $\begin{array}{r}\text { Rho } \\
P\end{array}$ & $\begin{array}{l}0.36 \\
0.02\end{array}$ & $\begin{array}{c}0.34 \\
0.009\end{array}$ & $\begin{array}{c}0.36 \\
0.007\end{array}$ & $\begin{array}{l}0.33 \\
0.01\end{array}$ & $\begin{array}{c}0,051 \\
0,81\end{array}$ & $\begin{array}{c}-0,29 \\
0,15\end{array}$ & $\begin{array}{l}0,16 \\
0,44\end{array}$ & $\begin{array}{c}-0,34 \\
0,09\end{array}$ \\
\hline
\end{tabular}




\section{Table 6(on next page)}

Comparison of the frequencies (\%) of PD-1/PD-L1 positive T and B lymphocytes in ALD patients with CTP class $\mathrm{C}$ versus controls based on patients'gender.*

* Mann-Whitney test; p1- ALD males with CTP class C vs ALD females with CTP class C; p2ALD males with CTP class C vs male controls; $p 3-$ ALD females with CTP class C vs female controls 


\begin{tabular}{|c|c|c|c|c|c|c|c|c|c|c|c|}
\hline \multirow{3}{*}{$\begin{array}{l}\text { Variabl } \\
\text { e }\end{array}$} & \multicolumn{4}{|c|}{ ALD and CTP class $C$} & \multirow[b]{3}{*}{$\mathrm{p} 1^{*}$} & \multicolumn{4}{|c|}{ Controls } & \multirow[b]{3}{*}{$\mathrm{p} 2^{*}$} & \multirow[b]{3}{*}{ p3* } \\
\hline & \multicolumn{2}{|c|}{ Males $(n=13)$} & \multicolumn{2}{|c|}{ Females $(n=4)$} & & \multicolumn{2}{|c|}{ Males $(n=16)$} & \multicolumn{2}{|c|}{ Females $(n=9)$} & & \\
\hline & Median & $\begin{array}{c}5-95 \\
\text { percentile }\end{array}$ & Median & $\begin{array}{c}5-95 \\
\text { percentile }\end{array}$ & & Median & $\begin{array}{c}5-95 \\
\text { percentile }\end{array}$ & Median & $\begin{array}{c}5-95 \\
\text { percentile }\end{array}$ & & \\
\hline \multicolumn{12}{|c|}{ PD-1 positive cell subsets } \\
\hline CD4+ & 17.29 & $4.90-35.64$ & 28.74 & $20.54-33.45$ & 0.10 & 21.07 & $8.40-9.64$ & 14.20 & $6.55-30.67$ & 0.24 & 0.07 \\
\hline CD8+ & 22.99 & $4.17-70.50$ & 33.24 & $16.19-65.89$ & 0.32 & 25.57 & $7.55-7.51$ & 21.11 & $\begin{array}{l}11.28- \\
43.08\end{array}$ & 0.40 & 0.50 \\
\hline CD19+ & 3.53 & $0.24-16.03$ & 13.34 & $4.22-24.84$ & 0.04 & 2.54 & $0.78-9.39$ & 1.66 & $0.35-14.70$ & 0.32 & 0.02 \\
\hline \multicolumn{12}{|c|}{ PD-L1 positive cell subsets } \\
\hline CD4+ & 0.74 & $0.02-2.45$ & 6.05 & $0.83-11.94$ & 0.02 & 1.06 & $0.26-5.10$ & 1.83 & $0.10-4.03$ & 0.14 & 0.0503 \\
\hline CD8+ & 0.45 & $0.07-1.51$ & 3.77 & $1.20-8.88$ & 0.005 & 0.97 & $0.13-2.43$ & 0.89 & $0.18-2.88$ & 0.12 & 0.03 \\
\hline CD19+ & 0.78 & $0.01-7.45$ & 8.63 & $1.47-21.01$ & 0.03 & 0.69 & $0.25-8.77$ & 0.45 & $0.07-1.52$ & 0.74 & 0.006 \\
\hline
\end{tabular}




\section{Table 7 (on next page)}

Correlations of the frequencies (\%) of PD-1 and PD-L1 positive lymphocytes with mDF, MELD and CTP scores in ALD females (Rho- Spearman rank correlation coefficient).*

*CTP- Child-Turcotte- Pugh score; MELD- Model for End-Stage Liver Disease; mDF- Maddrey's Discriminant Function; Rho- Spearman rank correlation coefficient 


\begin{tabular}{|c|c|c|c|c|}
\hline Variable & & mDF & MELD & CTP \\
\hline \multicolumn{5}{|c|}{ PD-1 positive cell subsets } \\
\hline CD4+ & $\begin{array}{r}\text { Rho } \\
P\end{array}$ & $\begin{array}{l}0.03 \\
0.91\end{array}$ & $\begin{array}{c}-0.06 \\
0.80\end{array}$ & $\begin{array}{c}-0.06 \\
0.82\end{array}$ \\
\hline CD8+ & $\begin{array}{r}\text { Rho } \\
P\end{array}$ & $\begin{array}{l}0.09 \\
0.73\end{array}$ & $\begin{array}{l}0.04 \\
0.88\end{array}$ & $\begin{array}{l}0.02 \\
0.93\end{array}$ \\
\hline CD19+ & $\begin{array}{r}\text { Rho } \\
P\end{array}$ & $\begin{array}{l}0.19 \\
0.46\end{array}$ & $\begin{array}{l}0.18 \\
0.47\end{array}$ & $\begin{array}{l}0.27 \\
0.27\end{array}$ \\
\hline \multicolumn{5}{|c|}{ PD-L1 positive cell subsets } \\
\hline CD4+ & $\begin{array}{r}\text { Rho } \\
P\end{array}$ & $\begin{array}{l}0.35 \\
0.16\end{array}$ & $\begin{array}{l}0.20 \\
0.43\end{array}$ & $\begin{array}{l}0.21 \\
0.40\end{array}$ \\
\hline CD8+ & $\begin{array}{r}\text { Rho } \\
\mathrm{P} \\
\end{array}$ & $\begin{array}{c}0.48 \\
0.043\end{array}$ & $\begin{array}{l}0.29 \\
0.24\end{array}$ & $\begin{array}{l}0.27 \\
0.29\end{array}$ \\
\hline CD19+ & $\begin{array}{r}\text { Rho } \\
\mathrm{P}\end{array}$ & $\begin{array}{l}0.26 \\
0.29\end{array}$ & $\begin{array}{l}0.12 \\
0.63\end{array}$ & $\begin{array}{l}0.16 \\
0.53\end{array}$ \\
\hline
\end{tabular}

